\title{
Chapter 21. The Multiple Directions of Social Progress: Ways Forward
}

Erik Olin Wright, Nancy Folbre, Jenny Andersson, Jeff Hearn, Susan Himmelweit, and Andrew Stirling

\section{Summary}

This chapter engages with three important themes of the larger report: the meaning of progress, its uneven nature, and obstacles to future progress. It also considers a number of political and economic alternatives aimed to overcome these obstacles, emphasizing the need for diverse strategies, open-minded experimentation, and scientific assessment.

While it may be impossible to ever reach agreement, the effort to calibrate different interpretations of progress remains an important exercise for political deliberation about how to make the world a better place. The very hope of moving forward implies some agreement on a destination. All of us must take responsibility for the future.

Our discussion emphasizes the complexity and multidimensionality of the interpretive debate, but also calls attention to its ideological character. Social actors-individuals, groups, and even academic disciplines--tend to define progress in ways that serve their own interests. In a way, distributional conflict undermines our very efforts to better understand and mediate such conflict.

The uneven character of progress is manifest in many different domains. Increases in the global reach of formally democratic institutions have been accompanied by growing concerns about their stability, efficacy, and consistency with democratic ideals. Successful economic 
development has created a new category of "middle-income" countries, even as it seems to have contributed to income polarization within many at the top.

The so-called "welfare state" was a major advance in the $20^{\text {th }}$ century. Government programs have expanded education, improved health, and created new forms of social insurance in many areas of the world. But slower economic growth and intensified social divisions in recent decades have created pressure for cutbacks. Many governments can no longer effectively tax or regulate corporations that have the power to relocate and minimize such inconveniences. In both Europe and the U.S., austerity-based policies are reducing public support and services for many vulnerable groups, including single mothers, students, the long-term unemployed and pensioners.

In most, if not all countries, women have gained greater access to education, political rights, and economic opportunities. However, increases in their formal labor force participation seem to have stalled, and women continue to shoulder a disproportionate share of the burden of caring for dependents. Public policies that support family work, such as subsidized child care and paid parental leaves from work, vary considerably in coverage both within and across countries. In the U.S., highly-educated women are able to bargain for family-friendly benefits; in large metropolitan areas they can easily hire low-wage women migrants to reduce their own family care burdens. Gender differences are now heavily inflected by differences based on citizenship, race, and class.

Economic inequality has also undermined progress toward environmental sustainability. Innovative new technologies offer ways of averting disastrous levels of climate change and ecological damage. But their implementation is often blocked by groups with powerful interests in the status quo who are protected from (or unconcerned by) the long-run consequences of their 
actions. Likewise, both political and economic power shape the direction of scientific and technological change, with little scope for democratic participation.

Why has progress been so uneven? Existing forms of capitalism both concentrate economic power and discourage the provision of public goods. But class differences alone cannot account for patterns of inequality based on citizenship, race/ethnicity, gender, and many other dimensions of group identity. Differences in collective bargaining power often lead to unfair and inefficient outcomes. While democratic institutions offer a means of negotiating better solutions, they currently seem inadequate to the task. Social science itself has yet to provide much assistance.

Yet social science theory and research suggest that a number of emerging institutional innovations could contribute to the development of a more collaborative, democratic and egalitarian society. Rather than putting democracy at the service of the market, we could put the market at the service of democracy. The expansion of non-capitalist firms, including worker cooperatives, employee stock ownership, social enterprises, and other hybrids could contribute to the development of a "cooperative market economy." Improved regulation of private enterprises - especially the financial sector--could protect the public interest. Progressive tax and transfer policies could reduce economic inequality. The public sector could improve, streamline, and expand the provision of health, education, and care services,

Some specific examples of these strategies include successful large-scale worker-owned businesses such as Mondragon, community-based credit unions, forms of co-management by owners and workers known as "economic bicameralism," proposals for universal basic income and care services. Possible innovations in political decision-making include sortition legislatures (which, like juries, require the random participation of citizens) and participatory budgeting. 
Social scientists don't have all the answers. But the only way we will ever find them is by moving beyond the critique of existing institutions toward a more focused and inventive process of exploring new ones.

\section{Introduction}

There are strong historical links between the social sciences and the idea of progress. The modern social sciences were part and parcel of the building of nation states in Europe from the seventeenth century on. They came together around Comte's positivist notion of change, according to which modern societies evolved through predictable stage-driven trajectories. Social scientists, hoping to master messy processes of social change in capitalist societies, aspired to displace the authority of previous beliefs in human destiny. The idea of progress represented a shift from notions of religious sovereignty to the idea of man-made change based on scientific rationality, steady improvement in technology, and secular political will. Such Enlightenment conceptions marched the social sciences into the contemporary era. Notions of linear change were reproduced in twentieth century conceptions of modernization as a process of universal development steps. They remain deeply embedded in both Marxist and pro-capitalist world views. Such notions were, however, never universally shared, and evoked considerable criticism. By the 1960s, the Western-centric worldviews of modernization theory were vehemently challenged, and so were attempts to use the social sciences to implement a Western world view of modernization.

The 1960s, marked by a return of critical theory, Marxism, and the rise of feminism and postcolonialism, saw both a formidable outreach of social science and growing awareness of its 
problematic relationship with the exercise of political and economic power. As collateral damage, confidence in the possibility that social science could successfully shape reformist projects was undermined. The very notions of "progress" and "modernity" were problematized, often bracketed in an effort to inoculate against their ideological undertones. At the same time, a turn to narrative, discourse and subaltern voices created a great plurality in conceptions of social change while emphasizing that notions of progress directly linked to capitalism, technology and forms of growth constituted a historically contingent Western process of modernization (see discussion in Chapters 3 and 4). Many of these critiques have been led by intellectuals and activists from and in the global South, and the Third or postcolonial worlds, where faith in progress has long been questioned (see, for example, Said 1978; Spivak 1987; Mies 1999; Santos 2014, amongst many others).

Challenges to progress are rooted in profound inequalities in world development that endured during the long post-war period of Western-driven world integration and in unexpected defections from commitments to democracy itself. The International Panel on Social Progress stands at a crossroads. The social sciences urgently need to produce an account of progress that stresses its universal aspects while not losing sight of social differences, plural values, and multidimensional priorities. These profound issues demand a global perspective that takes account of both social conditions and scholarship in postcolonial, Third World, global South perspectives, as well as insights from feminist and critical race theory.

The chapters of this report build some consensus on how social scientists define progress, but they also stress the late hour. The global climate has been destabilized. The financial crisis has created new uncertainties regarding turbulent market forces. Intensified economic inequality and insecurity, surges in international migration and refugee flows, and a resurgence of 
nationalism and racism, among other threats, loom large. In 2017, the Bulletin of the Atomic Scientists set its famous doomsday clock to two minutes to midnight, where it had not been since the Cuban missile crisis of 1962.

The central values of progress include democracy, equality of opportunity, mutual aid and care for dependents, and ecologically and socially sustainable economic development. While such values will never have a universal and fixed meaning, they constitute, as the Panel in its totality proposes, a compass for arriving at a sense of whether world developments are moving in the right or wrong direction. Rejecting a teleological view of progress is not at odds with retaining a rational kernel in the very approach to progress. This rational kernel is the idea that there are important potentials in the present for large-scale social improvements, and that these can be realized through action on a set of different levels of world politics, citizen participation and collective agency. These potentials may never be fully actualized, but they form the basis for human struggles to make a better world. We may no longer have good reason to predict progress, but must nonetheless work toward it.

In this chapter, we contribute to this effort by: first, reexamining the meaning of progress in a contemporary world; second, describing the uneven shape of progress as social improvement; third, identifying the main obstacles to progress in the world today; and fourth, outlining a set of ideas or practical utopias for the twenty-first century.

\section{The Meaning of Progress}

The concept of progress in the Western tradition is directly linked to the notion of the future. The invention of the future, as the German historian Reinhart Koselleck (2004) has 
remarked, came from the idea that coming horizons of time would embody improvements wrought by rationality, technology, and industry. The future, unlike destiny, would emerge as a secular space made by people. This secularization of destiny gave birth to the modern idea that progress would require changing the power structures of absolutist societies. The Enlightenment conception of modernity also gave rise to the notion that European societies occupied the lead on an axis of time, with other parts of the world lagging behind.

Many twentieth-century social theorists (including Luhmann 1995; Elias 1996; Dewey 1935) also emphasized the crucial link between the future, human rationality, and social imagination, arguing that the concept of utopia could help counter notions of social development predetermined by economy or technology. But while a future equated with progress has long shaped the social sciences, the relationship between the two has been called into question since at least the 1970s. The IPSP also challenges confidence in a technologically pre-ordained better future based on the liberal, democratic values of Western capitalist societies.

Social scientists must confront the possibility of future crises that threaten the very idea of progress, raising issues of growing inequality within affluent countries, between countries of the North and the South, and also between living and unborn generations of humanity. We must take long-term perspectives into account, and encourage what sociologists Barbara Adam and Chris Groves term "caring for the future" (Adam and Groves 2007), especially in the face of the possible irreversibility of social and environmental changes.

\subsection{Progress as social improvement}


However difficult it may be to maintain confidence in any grand narrative of progress, many of the chapters in this report show that the world has witnessed significant improvements since the mid-twentieth century. Technological advances have helped bring the world closer together, reduced hunger, and improved life for many people. Medical science has made extraordinary advances. Global literacy has expanded and the gender gap in literacy has been significantly reduced. Infant mortality has declined and longevity increased. Economic productivity has grown. But other, less positive trends are apparent. Economic development has been accompanied by environmental degradation and looming climate catastrophe. The social, as well as the natural environment, has suffered, with intensified inequality, erosion of communities, and heightened vulnerability and precarity for many people in many parts of the world. Improvements in women's access to education and opportunity in many parts of the world have been accompanied by multiple revivals of patriarchal authority. The traumas of abrupt globalization have triggered a backlash of nationalist and, often, racist mobilization. This report as a whole paints a picture of humanity equipped with enormous unrealized potential.

To identify progress as social improvement rather than as a driving force of history immediately poses a number of difficult issues. Five are especially important: the multidimensionality of social progress; disagreements over the values that constitute progress; conflicting interests at stake in progress; beliefs about the causes and solutions to impediments to progress; and political struggles over progress.

\subsection{Multidimensionality}


First, the ideas of "social improvement" that necessarily underlie any understanding of progress are irreducibly complex, multi-dimensional and plural (Norgaard 1994). There are many values and goals relevant to making the world a better place and no way of meaningfully collapsing them into a single metric of improvement (Stirling 2011). The list is long and heterogeneous, and this inevitably means that there will be tensions, trade-offs and even contradictions among them (Ophuls 1997). Some of these are familiar. For example, for many people, two important values in play in social improvement are individual freedom and democracy: a world with more freedom and more democracy is better than one with less freedom and less democracy (Freire 2001). However, individual freedom includes, among other things, freedom to spend money as one wishes, and in a society with large inequality of income and wealth, this undermines democracy. In this instance, a full realization of democracy would require restrictions on individual freedom by either limiting private donations to political campaigns or significantly redistributing income and wealth. What this means is that even where there is a broad consensus on the list of values that constitute the stuff of progress, there can be considerable disagreement on the relative desirability of particular priorities and trade-offs.

\subsection{Disagreement over values}

Beyond disagreements over priorities, there is, of course, no real consensus on the underlying values themselves (see discussion in Chapters 1 and 2). This is the second difficult problem in talking about progress: some values used to judge progress are nearly universal; others are deeply controversial; and in some instances, the very meaning of a value is contested. 
Consider, for example, the widely discussed United Nations Sustainable Development Goals. ${ }^{1}$ Driven by decades of collective action by social movements (Redclift 1987; Doherty and Geus 1996; Bloom and Town 2003; and Perreaul et al. 2015), the seventeen internationally-adopted Sustainable Development Goals, were generated by an arduous process of international deliberation that sought some kind of broad consensus for what the report calls a "new universal agenda." As one might expect, most of the goals are not especially controversial. For instance, the second goal is "end hunger, achieve food security and improved nutrition and promote sustainable agriculture." Virtually no one would deny that ending hunger is a social improvement - although the inclusion of multiple indicators and targets by which to account for progress towards this goal may nonetheless be challenging to certain interests. But other goals in the agenda are much more controversial, such as the fifth goal, "achieve gender equality and empower women and girls," or the tenth goal, "reduce inequality within and among countries." While the desirability of eliminating abject poverty might be a near universal, gender equality certainly is not, and many people think that there is nothing especially objectionable about economic inequality as such. Furthermore, goals that are not on the list - such as religious freedom and tolerance, democracy, freedom of association, and so on - would be even more controversial internationally. Conflicts over the values that constitute social progress occur not just cross-culturally. Deep political and ideological divides over the values that are relevant for judging social progress occur within countries as well. Of particular salience are sharp disagreements over the values connected to equality and social justice. On the one hand, there are political orientations, typically identified with the 'right' of the political spectrum, which are

\footnotetext{
${ }^{1}$ Transforming our World: The 2030 Agenda for Sustainable Development. United Nations: 2015. available at https://sustainabledevelopment.un.org)
} 
deeply skeptical of egalitarian understandings of social justice. For many traditional conservatives, this skepticism comes from a view of society as an organic whole with functionally necessary hierarchies and inequalities. For some strands of libertarian conservatives, the rejection of egalitarian values is anchored in a survival-of-the-fittest worldview in which inequalities are celebrated, democracy is viewed with suspicion as empowering the weak, and aggressive competition is seen as legitimately producing winners and losers. While few people defend the idea of "might makes right" as a moral ideal, political movements often embody this principle as a practical orientation. From this perspective, social progress might be understood as people taking responsibility for their own welfare without expecting others to bail them out when they fail.

On the other hand, political orientations generally associated with the 'left' and often referred to as "progressive," are anchored in a more horizontal world view committed to egalitarian ideals of social justice and democratic ideals concerning the distribution of power. From this perspective, social progress can be defined by the degree to which a society assumes collective responsibility for individual well-being and fosters equality in access to the social and material conditions required for people to flourish.

Even when people seem to agree on the importance of certain values, it can still be the case that the real meaning of those values may is contested. Consider the value "gender equality." For many people, gender constitutes a simple binary rooted in nature. The value of gender equality is then simply a question of equality - especially equality of opportunity and power - between men and women. For others gender is a much more complex idea, not simply because gender relations are socially constructed rather than given by nature, but because gender is not a simple binary. Attending to gender includes the gendered construction and differential 
gender power of diverse femininities and masculinities; inequalities connected to gender diversity and sexual diversity, including LGBTIQA+ (lesbian, gay, bisexual, transgender, intersex, queer, asexual, and further non-normative genders and sexualities); and gendering as a process over time. The meaning of "gender equality" as a value is very different if one sees gender as a complex, multidimensional, and fluid social form.

\subsection{Interests and power: social progress for whom?}

Social progress is not simply a matter of a plurality of social values. The social changes implicated in social progress also affect the interests of different categories of people and institutions in multiple ways. There are winners and losers - endowed with contrasting kinds and degrees of power. Everyone might agree that a world with less poverty is better than a world with more poverty. But since eliminating poverty requires significant redistribution, there will be opponents to the policies needed to eliminate poverty. And the very fact of privileged access to resources means that these interests will often tend to enjoy greater power in the resulting struggles. These issues are especially acute when we think of social progress globally. Policies which advance certain values in the wealthy parts of the world may be at the expense of the less advantaged parts of the world. For example, nation-based anti-pollution regulations for a clean environment in wealthy countries may result in the displacement of polluting industries or polluting waste to the global South, for example (Allen 1992; Grossman 2006). Likewise, a reduced burden of domestic labor for citizens of the North may rely on the caregiving services of immigrant women withdrawn from their own families and communities (see chapters 1 and 17). 
Interests and values derive partly from different social positions, such as age, class, gender, and race, and their intersections. In some situations such dimensions may be analytically separable, with different logics and dynamics (Verloo 2016). Interests and values may look very different from changing individual and collective positions; what may benefit, say, young people may not benefit those older - hence calls for intergenerational and other cross-dimension solidarities (Hearn 1999, Bengtson and Oyama 2007).

In addition, both capitalism and authoritarian regimes, whether political, religious or technological in flavor, are important in shaping, indeed driving, media formats and the privileging of certain technologies and technological platforms with the social adaptations they require. Such politico-technological developments are increasingly relevant in the very construction of interests and values through the power and influence of media, education and many other institutional forces.

\subsection{Uncertain means and ends}

Deeply connected to the complexity of the values and interests implicated in social progress is a fourth problem: conflicting beliefs about how to improve the realization of any given dimension of social progress. This is where social science probably has the most to contribute. In order to realize the potential for social improvement we need to properly diagnose what it is about existing social structures, institutions and processes that foster or impede progress on different values; and, given the diagnosis, we need good social scientific understanding of viable alternatives in order to formulate proposals for social change that would effectively foster those values. Neither ends nor means are self-evident to those concerned, and 
thus the spontaneous beliefs about what needs to be done to improve things are often deeply flawed. Given these diagnoses, formulation of proposals for social change that would effectively foster desired values requires good social scientific understandings not only of diverse viable alternatives, but also of the pluralities of relevant perspectives that are taken on these (Stirling 2011).

Of particular importance here is the problem of unintended consequences of efforts at social improvement (Veld 2010). It is one thing to argue that a particular policy of social change would benefit certain groups of people or directly advance some social value, and quite another to anticipate the full range of side-effects that might harm other values or even ultimately undermine the original direct purposes of the policy. A good example is the contrast between means-tested and universalistic programs for reducing poverty (Wilson 2012). On the face of it, means-tested programs might seem preferable since for any given level of state funding more money can be directed at poverty if only poor people receive the funds. But universal programs may actually provide more real benefits to the poor. Means-tested programs define a clear division between beneficiaries and non-beneficiaries of the policy; universal programs create a broader coalition of people who receive some benefit, and thus in the long term, universal programs receive greater public support. More focused social scientific research is needed to establish and analyze this dynamic of policy feedback.

Beliefs about the best means to achieve a given social goal are filled with controversy, both because social scientific analyses frequently go against commonsense explanations of social problems and their solutions, and also because among social scientists there are often serious disagreements over the diagnosis of problems and the desirability of alternative solutions. To take just one example, nearly everyone agrees that reducing poverty would constitute social 
progress. The mainstream 'commonsense' understanding of poverty by many people in wealthy countries (Dator et al. 2015; Edwards and Cromwell 2006; Hess and Kalb 2003; Allan et al. 1999; Christophers 2009; Le 2010; Curran 2002), is that poverty exists because poor people generally lack a work ethic and other personal attributes needed to get out of poverty. Such highly individualistic "blame the victim" explanations are also prominent in the mass media. If one accepts this diagnosis, then the solution is to increase pressure on poor people to take more responsibility for their own fate. Relatively few social scientists agree with this 'commonsense' diagnosis, but they disagree over what are the most critical social causes of poverty and therefore what needs to be done. Some argue that the core problem is deficits in human capital caused by inadequate school provision, chaotic neighborhoods, and other social conditions. The solution, therefore, is intensive efforts at improving educational opportunities for the poor. Others argue that the most fundamental problem is the nature of job opportunities, labor markets, and class structures in capitalist economies. Real progress to eliminate poverty, therefore, requires a transformation of these basic socio-economic structures.

\subsection{The politics of social progress}

Because of the issues we have been discussing - the multidimensionality of social progress, disagreements over values, conflicts of interest, and asymmetric power - the possibility of social progress is always deeply contested. Some discussions make it seem that a highly idealized conception of a 'good social planner', well-informed by relevant evidence and social theory, could simply nudge society in the right direction. For such an enlightened social planner, the main problem to be solved is finding the "optimal" policy, not overcoming the powerful 
interests and coalitions opposed to particular forms of progress. This is a fantasy. Social progress requires more than simply enlightening people; it requires political struggle.

The challenge of overcoming opposition to social progress is especially acute when progress involves matters of inequality and social justice. Those who benefit most from injustice are also powerful. Indeed, the very processes that generate unjust inequalities in income and wealth also generate associated inequalities in power sufficient to obstruct progress. What this means is that it is insufficient to have a clear understanding of what needs to be changed in order for there to be social improvements in social justice; there also needs to be sufficient solidarity and collective capacity to successfully challenge the powerful in political struggles over the needed social changes.

This gets to the heart of perhaps the most difficult problem in thinking about social progress. We know much about the causes of a wide range of social problems. We can track the trajectory over time in how some things have become better, and others worse, with respect to different values. There are many good, viable proposals for how to make things better, and we even know much about the obstacles to implementing these proposals. What we do not really know is how to create and assemble the necessary political forces to overcome these obstacles.

\section{The Uneven Direction of Progress and Problems of Reversal}

There is no simple "bottom line" in taking stock of social progress in the world today. The issue is not simply that the pace of progress varies both across the different dimensions of progress and across different regions of the world. A crucial additional challenge lies in questions of orientation (Stirling 2010). Complex interactions between the forces through which 
social progress occurs along its diverse dimensions and the contingency of political struggles mean that the direction of social progress is often uncertain (Collingridge 1983; Leach et al. 2010; Stirling 2012; Hess 2016). For instance, the social movements that social science has associated with progressive coalitions in the past might have a more ominous role in the present, as populist mobilization increases in strength. A turn to individualization as the major force for social change in recent decades may also erode capacities for collective action, and force the need to find new mechanisms of democratization and new vehicles of group politics. Many of the problems of the world, ranging from climate change to development issues and the rise of authoritarianism, are not manageable at the level of the individual but will require collective solutions on levels from supranational and world institutions, to interest groups, class action, social movements and party politics.

The chapters of this report chart many of the uneven, precarious trends on different dimensions of social progress, and we will not attempt to summarize all of these here. Instead, we will focus on those dimensions of - and directions for - social progress that pose the most serious challenges for the world today: democracy; class, inequality and economic precarity; the welfare state; gender; the environment, and science and technology.

\subsection{Democracy}

Assessing the extent and forms of progress (and sometimes regress) on the dimension of democracy is especially complex both because of disagreements over the meaning of democracy and because of the highly context-dependent nature of the specific institutional forms that advance the value of democracy in different historical conditions. 
The value of democracy has been specified in many different ways. Sometimes it is restricted only to the formal procedures through which political officials in the state are chosen. Other times it taps a much broader idea of political equality and collective self-determination. In this broader notion, the fundamental value underlying the ideal of democracy is that all people should have equal access to the necessary means for empowered participation in decisions that affect their lives (Wright, 2010, chapter 2). Understood in this way, democracy as a value does not simply apply to the state; it applies to all arenas of social life in which decisions significantly affect one's life. One can speak of a democratic workplace, a democratic family, a democratic church, as well as a democratic state.

If equal access to the necessary means for empowered participation in decisions is the central criterion for democracy, then a core indicator for democratic progress is the extent to which the least powerful segments of a society gain access to such participation. This is where the problem of context-dependence enters. In highly unequal societies with significant segments of the population being marginalized, the ability of the most disadvantaged to engage in vigorous public protest, including disruptive protest, could count as an indicator of increasing democracy. In a much more egalitarian society in which there are effective channels of meaningful political participation for all, disruptive protests could signal an erosion of democracy. In some contexts, forms of direct, participatory democracy can be highly empowering to the least powerful segments of society; but in other settings, participatory democracy can be manipulated by the rich and powerful, special interests, or sinister forces.

In considering the means to pursue democracy in this sense, one of the most important insights from the social sciences today is that social progress does not necessarily display a ratchet-like character in which gains along some dimension, once achieved, cannot be reversed. 
While sociologists have noted the 'disorganization' of Western capitalism in the period from 1970s onwards, with ensuing fractures of national communities and progressive coalitions, until recently most social scientists saw democracy as an unquestioned, broadly held value, at least in the Western world, and that processes of democratization, once achieved and stabilized, were irreversible. Chapter 1 of this report proposes that this is not the case and this deserves to be underlined in the light of ongoing developments. This raises the question of the conditions under which democracy might prove in fact to be fragile even in long-standing liberal regimes and just to what extent the current authoritarian turn might threaten democracy.

Two broad, contradictory trends have marked the progress of democratic values in recent decades. On the one hand, the proportion of the world's population that lives in states with formally-claimed democratic institutions is greater today than at any time in the past. The dissolution of the former Soviet Union led to the emergence (or in some cases, re-emergence) of a number of democratic states. And while it is more difficult to establish the extent to which these formal institutions meet the minimum criteria for substantive democracies - the rule of law, "free and fair" elections that incumbents can lose, open political debate, and so on progress seems evident on this front as well. Easy access to new information and communication technologies has improved the potential for political organization and participation, even if such technologies have also enabled parallel and sometimes false channels of information, and a new propaganda war.

On the other hand, in certain critical ways the "democraticness" of democratic institutions has declined in many traditional stable liberal democracies and the future prospects for democracy in countries without a long tradition of liberal democracy are less promising than 
was once thought. There are many indicators of declining democratic health in what are generally thought of as secure democracies: ${ }^{2}$

- declining levels of traditional forms of political participation in most nations;

- $\quad$ a decline of traditional mechanisms in the media and political parties for robust public deliberation of political issues;

- $\quad$ the development of new media and communication technologies, such as social media, that has generated a proliferation of channels of false information, hate speech, and propaganda, which alters democratic debates significantly, albeit in ways that it is today difficult to fully evaluate;

- $\quad$ increasingly sophisticated forms of state surveillance through the use of information technologies;

- $\quad$ increasing levels of popular cynicism about politicians and declining trust in democratic institutions;

- the erosion of voting rights through national or state-level restrictions;

- an increasing institutional "democratic deficit" because of displacement of significant forms of decision-making from democratically-accountable bodies to various kinds of unelected commissions. ${ }^{3}$

Taken together, these processes are reflected in the serious challenge to liberal democracy embodied in the rise of illiberal authoritarian politics, as demonstrated by the election

\footnotetext{
${ }^{2}$ Many of these trends are discussed in chapters 9 and 14.

${ }^{3}$ This has been especially salient in the European Union, where elected bodies at the European level are particularly weak, but many decisions of considerable importance are nevertheless made at that level of governance.
} 
of Donald Trump in the U.S. and the rise in popularity of ultra-right wing parties in Germany, Austria, the Netherlands, and France. In recent years, these parties have gone further than their earlier populist attacks on liberal values: they are mounting a strategic and systemic attack on liberal institutions, including fundamental rights of citizenship, the rule of law, free press and cultural life. They are seriously threatening ethnic, political, and sexual minorities. The European Union, which had its origins not only in desires for market integration, but also and importantly, in response to fascism, in the hope for enduring peace on the European continent, has become a central arena of extreme right-wing parties, threatening not only the potential of the EU to respond to both financial crisis and the needs of migrants, but also its very capacity to defend democracy.

In countries without stable traditions of liberal democracy, the prospects for democracy in the future are also much more ambiguous than previously thought. While there were always debates on these issues, until recently, social scientists generally argued that economic development would eventually lead to democratic reform more or less automatically. This expectation has been discredited. The example of China has shown that authoritarianism can not only be a successful development strategy, but that development can reinforce rather than undermine authoritarianism, although the long-term future of politics in China is quite open. Furthermore, quite apart from the ambiguities in the connection between economic development and democracy, the advance of democratic institutions in some parts of the world has been undermined by significant increases in various forms of political violence. Many political boundaries established through international negotiation have proven unstable, with ethnic conflict fanning the flames of civil war. Increased international economic competition has also been linked to the intensification of ethnic conflict in many countries (Chua 2004). 
What is perhaps especially worrisome for the global prospects for democracy is that in some countries in which formal democratic institutions were instituted in recent decades and where democracy seemed to be consolidating, strong, illiberal and authoritarian movements have emerged. This is especially striking in Russia where democracy has become a shell, but similar trends are present in certain other Eastern European countries, as well as Turkey, the Philippines, and, in a more ambiguous way, India.

\subsection{Inequality}

Despite many disruptive fluctuations in economic growth, global labor productivity has grown significantly over the last four decades, with vast potential for improvement in living standards. The actual gains, however, have been unequally distributed both on international and national levels (see discussion in Chapters 3 and 14).

New sources of historical and contemporary data offer important new insights into distributional trends, revealing somewhat contradictory outcomes. On the one hand, rapid economic growth in countries such as China, Korea, and Mexico has created a global category of middle-income countries that confound a longstanding tradition of sorting countries into the binary categories of developed and developing. On the other hand, the difference in living standards between countries at the top and the bottom of the global income distribution has widened considerably, creating enormous pressure for the migration of economic, as well as political refugees. By one estimate, about 60 percent of a person's income is determined merely by where she or he was born (Milanovic 2012). 
Most empirical attention to economic inequality focuses on the national level, where its multidimensional aspects can be more fully explored. Here too, progress seems ambiguous. On the one hand, material standards of living have improved for most people within developed economies since the middle of the twentieth century. Expanded public provision of health care and pensions in the second half of the twentieth century has had a particularly important effect on raising real living standards of people at the bottom of the income distribution (Weil 2015). And even in terms of the components of living standards purchased in the market, the material standards of living of people in the lower deciles of the income distribution have generally improved even in the face of growing inequality in labor market earnings. Virtually all lowincome households in wealthy countries have refrigerators, modern heating and electricity, and televisions; over two-thirds of households in the bottom quartile own smartphones.

On the other hand, both income and wealth inequality have increased dramatically in many developed economies. In recent decades income from capital has far outpaced income from labor, and the rate of return on capital has exceeded the rate of economic growth. In the U.S., where public policies have done little to mitigate these trends, the top percent of the population has dramatically increased its share of income and the average household income of the bottom 50 percent has stagnated since the 1970s (Piketty 2014). In France, by contrast, the incomes of the bottom 50 percent of income recipients grew at approximately the same rate as national income per adult over the same period. ${ }^{4}$ Earnings inequality has also intensified sharply in the U.S. Some economists explain this trend as the result of technological changes that have

\footnotetext{
${ }^{4}$ For a summary of more recent but as yet unpublished research by Thomas Piketty, Emmanuel Saez and Gabriel Zucman that makes this comparison, see Patricia Cohen, "A Bigger Economic Pie but a smaller slice for half of the U.S.," New York Times, December 6, 2016, available at http://www.nytimes.com/2016/12/06/business/economy/abigger-economic-pie-but-a-smaller-slice-for-half-of-the-us.html
} 
increased the demand for skill, combined with a reduction in the supply of college graduates. However, median earnings of college graduates have changed little in recent years, and growth in earnings is concentrated at the very top, among employees in the financial sector (Folbre 2016; Lin and Tomaskovic-Devey 2013).

Meanwhile, at the bottom of the earnings distribution, the decline of unionized industrial employment has been accompanied by a rise in precarious employment, including temporary and involuntary part-time jobs. These changes have been driven largely by globalization and institutional restructuring, though technological change may also have played a role (Kalleberg 2011).

A global "precariat" has also emerged, harbinger of what may be a major change in class structure (Standing, 2011). Migrant workers who lack citizenship rights are particularly vulnerable to insecure employment. Their interests are often, in contemporary consumer capitalism, in conflict with those of white workers whose faltering wages in the last decades have led to a demand for ever cheaper consumer goods. This global conflict in the division of labor is increasingly played out not only as a division between increasingly skilled labor in the western world and manual labor in the developing south, but also as conflicts and perceived conflicts of interests between white workers and immigrant labor in the West. Brexit showed the unpredictable nature of the political responses that might stem from this, and future elections in Europe and elsewhere may underscore that, even if migrant workers do not reduce jobs available to white working class, feelings of threat provide a breeding ground for right-wing populist politics which make it ever more difficult to articulate notions of common class interests and progressive coalitions. 


\subsection{Progressive coalitions and the erosion of the welfare state}

In the decades following World War II, many social scientists believed that progress could be understood as the completion of Marshall's social citizenship revolution through an expanding welfare state that redirected a significant proportion of the resources produced by the economy to social purposes (Marshall 1950). Virtually all the democracies that climbed the ladder to affluence in the twentieth century devoted an increasing share of their Gross Domestic Product (GDP) to social insurance and protection, vastly improving the health and income security of their populations and reducing inequality in living standards (Lindert 2004). Most research to date on social policy and the welfare state has focused on Western Europe, North America, Australia, and New Zealand. The focus is now shifting, and with good reason: most of the world's population lives in less affluent countries, and policy trajectories there differ substantially and offer new possibilities for innovation. Increases in public spending in Latin America, in particular, represent an important trend (UNRISD 2010, 2016).

However, the once powerful expectation that expansion of the welfare state would accompany economic growth has been shaken. In sixteen of the most affluent democracies, government spending as a percentage of GDP declined between the late 1980s and 2008 (Brady and Lee 2014). OECD statistics show further declines in many countries since that year. ${ }^{5}$ In the U.K., a period of public investment between the mid-1990s and the mid-2000s came to a halt with dramatic cuts in expenditure and soaring levels of poverty, including a dramatic rise in the use of food banks and in the number of children growing up below the poverty threshold. Following the break-up of the Soviet bloc, centrally-planned redistributive programs have been

\footnotetext{
${ }^{5}$ See the OECD database at https://data.oecd.org/gga/general-government-spending.htm
} 
replaced by various national systems, and those with authoritarian political systems have largely eviscerated those social programs (Orenstein, 2008). The financial crisis of 2008 had devastating effects on social spending in southern European countries in particular and where cuts in unemployment and pension benefits have imposed shocking hardships (Petmesidou and Guillén 2014). In Greece, hit by the twin challenges of the refugee crisis at Europe's borders and its own debt-ridden economy, life expectancy is decreasing and suicide rates are rising.

Nevertheless, the welfare state remains a fundamental element of social progress. As demonstrated in many chapters of this report, social scientists generally believe that a publically funded and redistributionist welfare state is necessary to mitigate the shortcomings of capitalism. Public spending still represents considerably more than 30 percent of GDP in the U.S., Canada, Australia, Japan, most European countries, and a handful of other countries, and has been expanding in some areas of the world, especially Latin America. While some economists have blamed public sectors for faltering growth rates, empirical analysis of the relationship between government spending and economic growth in the U.S. and Europe has led to the opposite conclusion: public spending buffers the business cycle, boosts consumer demand, and improves the capabilities of the working age population (Lindert 2004) and is a form of social investment (Morel et al. 2011).

Social spending helps spread the costs and risks of caring for young, the old, the sick and the disabled. Unlike private insurance, which is subject to problems of adverse selection, public insurance can pool risk efficiently. Most redistribution through the state takes place over the lifecycle, with the working age population helping pay for both the education of the young and pensions and health care of older people. Socialization of support for dependents has particularly important implications for women, who have traditionally devoted more resources and more 
effort than men to family care. Some empirical studies of the distributional impact of social spending in both the U.S. and the U.K. show that members of most income groups receive benefits that are broadly similar to what they financially contribute (Hills 2014; Folbre 2008). Still, public transfers have an equalizing effect on opportunities for young children, in particular.

Social spending also has symbolic as well as economic valence, reflecting deeply held ideals of economic justice and concern for others. What then, accounts for the faltering role and declining size of the public sector despite positive —albeit slower-rates of economic growth? Part of the explanation lies within the public sector itself. Voters find it difficult to accurately assess the value of its contributions. Public spending sometimes fuels distributional conflict, especially when transfers are specifically targeted to a low-income population through meanstesting. Continuing increases in the relative share of the elderly population, combined with improvements in longevity and slower wage growth have raised legitimate fears regarding the sustainability of public commitments to retirees.

The bigger factors, however, derive from institutional changes that have taken place outside the public sector. The devolution of the formerly centrally-planned economies set the stage by removing the political pressure of competition from a more egalitarian - though clearly undemocratic_-economic system (Petras 2012). Austerity policies have led to major budget cuts, often with disproportionate impact on women and low-income families (Bargawi et al. 2016). Starved of necessary funds, some public programs have been forced to cut either the quantity or quality of services provided, further undermining public support.

Increased globalization and capital mobility have made investors less dependent on any specific national labor force and less vulnerable to regulation. Transnational corporations can relocate at will in search of lower wages and lower taxes. In recent years a large share of private 
as well as corporate wealth has essentially gained immunity from public oversight and taxation (Zucman 2014). Concomitant effects of globalization, such as the decreased power of labor unions, have contributed to political realignments. Increased international migration and ethnic diversity, combined with intensified income inequality, may also have undermined support for public spending (Alesina et al., 1999).

The conviction that free trade is always and everywhere economically advantageous functions as a key tenet of radical pro-market advocacy. On the other hand, feelings of economic vulnerability may lead to rash responses and false promises that protectionism will recreate once flourishing national industries. Far right populist parties on the European continent advocate a conservative form of welfare nationalism that channels funds in ways designed to maintain national and local authority. While social protection can in principle buffer vulnerable populations from the disruptions of globalization, it can also become a means of cementing clientelism and implementing old and new forms of gender and ethnic segregation.

The future nature of the state itself is in question. Research on the strong pro-market policies of recent decades emphasizes increased subordination of states to markets, and the increasingly tight connection between political and financial elites, as well as new possibilities for veto points and “winner-take-all-politics.” Public debt leaves governments profoundly dependent on financial markets, rendering large populations vulnerable to even small changes in interest rates. Regulatory failures have lead to financial bailouts and encouraged international tax evasion. Economic and political elites have more in common with their counterparts in other countries than their own fellow citizens, creating resentments that fuel populist backlash. Financialization and marketization have clearly reduced the egalitarian leverage of the welfare state. 


\subsection{The uneven progress of gender equality}

There is broad agreement among social scientists that in the past half century there has been significant, if uneven, progress toward gender equality, gender equity and gender justice in many parts of the world. Much of this progress is connected to improved access to education for girls and women in most — though certainly not all—countries around the world. Important gains have also been made in the area of legal, political citizenship and property rights. But these gains are not universal, and may not be permanent, especially when intersecting inequalities based on race, ethnicity, gender, citizenship and other dimensions of collective identity come into force. Some right-wing populist governments have taken aim at immigrants, including refugees, and this can have particularly serious effects on the status of immigrant women. In sum, "the elaboration of gender equality is closely aligned with the development of gendered citizenship, seen as inclusive of political and economic entitlements, access, and belonging and encompassing rights and obligations.” (Hearn and Husu 2016; see also Oleksy et al. 2011).

Another important area concerns health and bodily autonomy. Improvements in medical technology have reduced child mortality, and increased access to safe and reliable means of contraception and early-stage abortion have given many women more control over their reproductive decisions than they have enjoyed in the past. Violence to women and other forms of gender-based violence remain a major challenge for gender equality, even though they are now highlighted on many international governmental agendas. Interestingly, cross-national and crossstate statistical analysis of reduction in gender inequalities suggests that these may serve men's interests as well (Holter 2014). 
Evidence of economic progress is more mixed. Trends in formal labor force participation, relative earnings, the division of labor in unpaid work, and financial responsibility for the care of dependents reveal persistent — and in some cases worsening — gender inequalities. Women's participation in formal employment remains variable, relatively low in the Middle East and North Africa, and relatively high in OECD countries. Women increased their share of formal employment in OECD countries rapidly during the last third of the twentieth century. This trend has now leveled off. The record for low-income countries is more complex, with significant increases in women's employment over the last twenty years in Latin America, and declines in South Asia (especially India) (Elborgh-Woytek et al. 2013).

The stagnation of global manufacturing employment, combined with the growth of precarious and part-time employment and expansion of informal employment, does not bode well for future trends in female employment. Indeed, some economists argue that male employment patterns are converging toward female patterns, rather than vice versa (Standing 1999).

In virtually all countries for which data is available, levels of occupational segregation by gender remain quite high (Charles and Grusky 2004), although there has been some erosion especially in professional occupations requiring high levels of education. With the exception of some export-oriented manufacturing platforms in low-income countries, women tend to be concentrated in service sector jobs with relatively low wages. Even when they attain professional or managerial status, they are clustered in care industries (often in the public sector) where wages are more compressed.

Women continue to devote far more time to unpaid work and family care than men do, a factor that constrains their opportunities in paid employment. The impact of such constraints 
varies considerably by race and class as well as citizenship. Affluent families can outsource many domestic tasks to low-wage workers. In many developing countries, the absence of basic infrastructure like piped water at the domicile, easily accessible fuel and adequate and accessible sanitation facilities are particularly critical for reducing the burden of unpaid domestic work that is placed disproportionately on women and girls.

In the U.S., many European countries, and some Asian and Middle Eastern countries, large pools of low-wage migrants provide a cheap source of purchased care for children and the elderly, enabling them to send money home but depriving them of opportunities for a family life of their own. The global inequalities that induce them to migrate on these terms reduce the pressure on affluent countries to provide more public support for care.

Many policies embedded in the welfare states of Northwestern Europe (but now seriously threatened by budget cuts) make it easier for women to combine family work with paid employment, with positive consequences for female employment, family formation, and birth rates. Many Latin American countries have adopted progressive work family policies in recent years. In general, however, public support for family care remains low and uneven. Austerity policies aimed at reducing public spending in many developing countries since the 1980s and, more recently, in Europe, have set back progress toward gender equality. Such policies have had a disproportionately negative effect on those taking on responsibilities for unpaid care (mainly women), households with children (notably lone parents) and single women pensioners (Bargawi et al. 2017).

Changes in the organization of family life also reveal both positive and negative trends (see Chapter 17). On the one hand, time-use survey data from many countries indicate that differences between men and women's total work day (including both market and non-market 
work) are generally lower in high-income than in low-income countries (Burda et al. 2013). In many countries, modest increases in men's relative contributions to both housework and child care since the 1970s have been well documented. On the other hand, increasing rates of nonmarriage and/or unstable partnerships in many high-income countries have made childrearing a more risky and uncertain proposition. Below-replacement fertility levels may offer some environmental benefits, but they also disrupt intergenerational transfers (whether through the family or the welfare state). Growth in the percentage of children maintained by women alone, especially in the U.S., Latin America, and Southern Africa, has contributed to increasing child poverty. In some instances, mothers' improved access to earnings has been partially counterbalanced by a decline in father's contributions to costs of supporting and raising children.

While gender equality, and gender relations more generally, are often seen as related primarily to either family relations (as in the above examples), or formally labelled gender policy issues (for example, gender pay gap and violence against women), they are also relevant to what may appear to some as gender-neutral arenas, such as foreign policy, transport policy or environmental policy. Embedded gendering processes persist in what may be represented as seemingly "gender-neutral" or "non-gendered" arenas, such as state functioning, budgetary allocations, economic development, international relations, mobility, and so on (Hearn 2015).

Also, values and aspirations other than (gender) equality, such as democracy, freedom or simply care, are also constructed through gendered processes (Steans 2013). Economic crisis has highlighted gendered aspects and biases in policy development. Although some voices at both the World Bank and the International Monetary Fund emphasize that gender equality can promote economic growth, most members of the global financial maintain a 'strategic silence' on 
the gendered effects of macroeconomic policies. Deflationary policies and cuts in social spending tend to have a more negative effect on women than men (Young et al. 2011). In some countries, economic crises have initially depressed men's employment more, with larger delayed effects on women. The allocation of government expenditures, investments and spending on research and development often has more positive effects on men than women (Neumayer 2011). Male employment tends to be more concentrated in the private, corporate sector than female employment, encouraging men to identify more closely with that sector.

Gender equality policies offer important progressive tools, but are not unproblematic. The meanings of gender and sexuality are not fully captured by the male/female binary, and their multiplicity requires more serious attention in both theory and practice. If narrowly conceived, gender equality may feed an ideology of equality based on misleading and superficial appearances (Spade 2011). It may also reproduce heteronormativity and a form of Western neoimperialism, as exemplified in the debate on homonationalism (Duggan 2003; Puar 2007). But however circumscribed some gender equality policies may be, they should not be dismissed or underestimated (Hearn and Husu 2016).

\subsection{Uneven progress on the environment}

One of the most striking features of world politics over the past half century has been the rising salience of concerns about the environment. Initially driven by grassroots environmental and other social movements and now forming the single most voluminous arena for international law, pressures for improved international environmental governance have been major drivers of the institutional regimes constituting globalization. 
Social processes have tremendous effects on the environment and environmental flows. Unlike the formal organization of international political orders, the Earth itself knows no borders. Social, economic and political processes intersect and influence environmental processes. Economic and political justice are closely linked to environmental justice. Social and economic inequalities, including those based on class, gender, ethnicity, and citizenship, are antithetical to sustainability (Wilkinson and Pickett, 2009; Neumayer, 2011).

By the mid-2000s, the US and Canada, with 5 percent of the global population, accounted for 27 percent of global oil consumption; Europe, with around 10 percent of the global population, accounted for 24 percent. Per capita emissions within regions are also extremely variable. North America produces 20 tons of carbon dioxide per person per year, Europe about eight, Africa one (World Bank 2007). The rate of increase in fossil fuel consumption in Brazil, Russia, India and China is especially rapid.

Although worldwide debates over the environment are now dominated by the imperative need to halt anthropogenic global climate change, human assaults on nature also take many other forms, threatening similarly uncertain but possibly catastrophic consequences (Harremoes et al. 2002; Gee et al. 2013). Climate change and sea level rise (IPCC 2015), chemical contamination (Cranor 2011), accumulating toxic wastes (Allen 1992), atmospheric pollution (OECD 2012); ecological destruction (MEA 2008), soil erosion (UNEP et al. 2014), population growth (UN 2015), urban spread (UNDESA 2015), resource depletion (Meadows et al. 2005), food insecurity (IAASTD 2009), water deprivation (FAO \& WWC 2015), ocean acidification (Burke et al. 2011), landscape degradation (CPRE 2013), novel pandemic risks (Jonas 2013), antimicrobial resistance (Neill 2016), foodborne diseases (WHO 2015), nuclear accidents (FAIC 2012), ionizing radiation (UNSCEAR 2016), genetic interference (UNCTAD \& CGIAR 2013), 
weapons of mass destruction (OTA 1979), disruption of global material cycles (Rockström et al. 2009) and direct forms of oppression of other living beings (Singer 2002) all represent distinctive environmental challenges across various definitions of social progress. The grave intensity of each of these human impacts combine in a potentially-exponential "perfect storm" of cumulative interactions (Beddington 2009; WEF et al. 2014).

As with other aspects of social progress, however, general implications are easier to discern than specific imperatives for action. Despite many divergent views regarding the implications, magnitude and urgency of environmental challenges, convergence toward technocratic solutions is evident (Stirling 2015). One form of technocratic environmentalism is the view of many economists that a suite of technically sophisticated tax and subsidy policies could incentivize sufficient environmentally respectful behavior to effectively deal with most environmental problems. A more radical technocratic view, associated with analyses of the advent of a new 'Anthropocene' geological epoch (Hamilton et al. 2015), calls for intensified human control over the Earth, involving "management" of "planetary control variables" (Rockström et al. 2009). In such views, 'progress' becomes exemplified by new global institutions and infrastructures such as those argued to be required for 'climate geoengineering' in order to address global warming (Shepherd et al. 2009). Here, the emphasized gravity and urgency of environmental challenges are increasingly held to demand moves towards new forms of "environmental authoritarianism" (Beeson 2010) under which democracy is openly dismissed as a "luxury" that should be "put on hold" (Hickman 2010).

Under an alternative perspective, however, it is exactly these kinds of "fallacies of control" (Stirling 2015) and associated "cockpitism" (Hajer et al. 2015) that constitute the core of the problem. In this view, proliferating forms of environmental degradation are caused by the 
same kinds of oppressive social relations as those resisted by democratic struggle (Grove 1995; Castree and Braun 2001; Stirling 2014b). Alongside other more human forms of exploitation, environmental destruction can in this sense be seen as a symptom of powerful interests and privileged groups being insulated from the consequences of their exploitative practices (Goldman and Schurman 2000; Perreaul et al. 2015). In this view, the task of reversing adverse impacts on vulnerable natural environments presents effectively the same political challenge as resistance to more exclusively human forms of oppression. And in this analysis, social progress is best realized not by concentration of power in vertical global structures for planetary control, but by the reinforcing of mutualistic horizontal relations of solidarity, under which people in more equal societies are incentivized to exercise greater care not only for each other, but also for the environments in which all live (Stirling 2016).

\subsection{Uneven progress of science and technology}

Arguably, no other area of life is more implicated in debates about social progress than practices and discourses around science and technology, including related investments in education. More than any other aspect of society or politics, it is science and technology that tend to be afforded the main credit for the remarkable historical improvements around the world in which many people in different societies are experiencing unprecedented qualities of health and wealth, energy and communication services, mobility and leisure, shelter and material comfort (Broers 2005; Huesemann 2003). Yet it is equally important to acknowledge that not all consequences of research and innovation are positive, nor that beneficial directions for science and technology unfold automatically (Sveiby et al. 2012). 
Few would argue, for instance, that new kinds of tax avoidance, covert state or corporate surveillance (Zuboff 2015) or weapons of mass destruction constitute positive applications of science and technology. Yet many of these are highly active areas in contemporary innovation. Indeed, it is currently the case that the single largest area for public investment in science and technology around the world lies in military- and security-related applications (Science 2014b). The balance between benefits and risks in other areas of education, science, research and innovation, depends on the effectiveness with which these are governed.

In other words, not all technological innovation is driven most strongly by science. Collective action by governments or social movements can often be as important as academic, commercial or public research in steering progressive directions for technology. For instance, it is difficult to envisage the formative advent of nineteenth century urban sewerage systems, without the driving energy of Victorian philanthropism (Geels 2006). Nor are the enormous late twentieth century gains in health care credibly explained without reference to the enabling effects of welfare states.

Currently burgeoning forms of renewable energy, sustainable agriculture and ecological production were likewise all pioneered by marginalized activist organizations - often strongly opposed by institutions associated with mainstream science and technology (Joergensen et al. 1991). Appreciation of this breadth in the drivers of social progress is currently informing rising interest in the importance of social and grassroots innovation as means to achieve social progress (Smith et al. 2016).

A further irreducibly social and political factor shaping the roles of science and technology in the assisting or obstructing of social progress lies in crucial processes of resource allocation within research and innovation. Across areas as diverse as agriculture, 
pharmaceuticals, energy and materials, a host of economic and institutional factors determine patterns of investment across alternative possible trajectories for innovation ( Stirling 2014a). Many of these are entirely distinct from any direct measure of social progress. Indeed, the principal incentives bearing on existing research and innovation systems typically arise not in manifest public benefits, but in pressures to maximize private returns on investment. Even publicly-funded research tends to be strongly disciplined by prospects for onward commercialization, and this applies equally to the marketization of education, especially higher education, in many parts of the world.

So rather than focusing directly on wider human wellbeing, innovation activity in most countries of the world tends to be concentrated disproportionately around commercial considerations: the potential for raising rents on intellectual property (Chou \& Shy 2013) (Hilgartner 2009); appropriating value in associated supply chains (Kaplinsky 2000); or increasing market share across mutually interdependent products (Porte 1991). Innovations which do not seem as likely to offer prospects of these kinds of private benefits are typically much less enthusiastically developed. Open source innovation, distributed social practices or preventive health behavior may often be more effective at realizing social progress in any given area (Science 2014a). But these will typically be disfavored by a preference for scientific and technological advances that better enable the securing of private benefits.

However social progress is construed, then, there are no guarantees that interests and incentive structures operating within scientific research or technological innovation systems will successfully focus attention on challenges and opportunities prioritized in the wider society. Nor is this just a reflection of market failure to meet social needs since so much effort in research and innovation systems driven by public sector institutions is preoccupied with military and security 
technologies (OECD 2013, Alic 2007). Of course, the regular occurrence of 'spin-off' does to some extent mitigate the effects of this mismatch - where technologies pursued for one purpose yield benefits in some contrasting area (Chesbrough 2003). But this is a general phenomenon that applies irrespective of the main purpose in question. So, whatever the incidental benefits may be in particular areas, there can be no denying that efforts to realize social progress through science and technology can experience serious divergences between private incentives and the public good.

There are many reasons, then, to challenge the notion of any simple relationship between technological change and wider social progress. Without the right kinds of cultures, institutions and political economies, it is not possible for the most socially progressive innovations to develop in the first place - nor to be prioritized or to diffuse or advance in the required ways. The potential of science and technology to help realize social progress remains enormous. But it is essential to ensure appropriate incentives and encourage clarity, transparency, and accountability.

Policy debates overwhelmingly view the formative relation between technology and society in a one-way fashion. Each new innovation is seen as ushering in a wave of apparentlynecessary forms of onward organizational, behavioral, cultural and political adaptation, rather than the other way around. Various forms of 'technology roadmap' currently proliferate through much research and innovation policy (Phaal et al. 2004). What is striking, however, is the extent to which political imaginations are constrained merely to the two possibilities of 'forging ahead' or 'falling behind'. The main point of any roadmap, surely, is to enable steering in the right direction? Yet these policy documents typically feature just a single 'way forward'. The particular scientific and technological trajectories in any given sector that are highlighted in this 
way as the natural orientation for 'advance', are not necessarily those that best realize social progress, but those that are most favored under incumbent interests in that sector.

With futures increasingly conceived in these terms, wider debates also become preoccupied with competitive pressures merely to 'accelerate' emerging and converging technologies, rather than steering their directions. As anxieties grow over the implications of ever more competitive modes of globalization, these visions of disproportionately science- and technology-driven forms of social progress are intensifying. Meanwhile, governments and businesses around the world increasingly emphasize similarly driving roles of science and technology, asserting the importance of developing "population innovation readiness" (Eurobarometer 2005) for "knowledge societies" (Felt et al. 2008) and "pro-innovation policies" (Sveiby et al. 2012). Again, what is striking about this language is how much it is advanced without any reference to exactly which kinds of science, technology or innovation it is intended to favor and which to discourage.

In this way, adverse public reactions to some particular technology (like GM crops or nuclear power) are routinely branded "anti-science" - as if they represented indiscriminate opposition to science in general (Felt et al. 2013). This again entirely excludes the actuality that science and technology (like other kinds of institutional change) are branching evolutionary processes rather than a one-track race (Nelson and Winter 1977; Dosi and Nelson 1994; Williams and Edge 1996; Fagerberg 2003). Just as market competition is held to favor the maximizing of economic performance, so political contestation in democratic societies ideally would help to steer the trajectories for science and technology in the most socially desirable directions. In this light, all the language and apparatus summarized here around supposedly generally 'pro-innovation policies' or indiscriminately 'anti science' public reactions are not 
only deeply irrational and misleading, but actively serve to undermine this democratic process of steering (OECD 2010).

The implications of this picture of the politics of science and technology for the present report on social progress could hardly be more profound. Despite their uneven and contingent success, research and innovation are typically characterized as primary drivers of progress. Rather than being recognized as a choice among plural directions across multiple dimensions, they are reduced to a single one-track race. Scope for debate is thus restricted merely to queries over 'how much?', 'how fast?' or 'what risk?'. Crucial questions are neglected over 'which way?', 'who says?' and 'why?' (Stirling 2008). This seriously suppresses scope for democratic struggle and mature political deliberation over both the speed and the direction of social progress.

\section{Obstacles To Progress}

Some aspects of social progress may sometimes happen "behind the backs" of actors as simply the cumulative, unintended side effect of human action, but generally progress requires purposeful action - albeit often distributed and mutualistic rather than vertically-controlled (Kennedy et al. 2001, Pellizzoni 2004; Gloor 2006; Neil and McAdam 2010; Stirling 2015; Munoz, Erickson and Cutts 2016). Social progress doesn't just happen; it is made. The problem of generating progress on any dimension, therefore, depends in critical ways on the ability to identify the forces and processes that impede progress and the opportunities for reducing (or getting around) those obstacles. 
In what follows we will review four obstacles to continued social progress: existing forms of capitalism; collective conflict based on class, gender, race and citizenship; the current limits of democracy; and social science.

\subsection{Existing forms of Capitalism as Obstacles to Progress}

The term "capitalism" gets used in a wide variety of different ways by social scientists. Sometimes it is used as almost the equivalent of market economy. Other times as a way of talking about a broad social system, not just an economic structure. When we use the term “capitalism" as a general, abstract concept, we are referring to a particular form of market economy: a market economy consisting of privately-owned, profit-seeking firms employing labor hired from a labor market. Concrete capitalist economies come in a wide variety of forms. It is also the case that in all real economies, different varieties of capitalism are entangled, often hybridized, with other hierarchical systems or social contracts based on gender, race and citizenship (Folbre 2013; Mills 1999) as well as a wide variety of non-capitalist forms of economic activity including welfare state provisions that contribute to the reproduction of its labor force, various forms of subsistence production, and a wide range of nonmarket, collaborative community-based economic activity (Gibson-Graham 1996).

Capitalism has always had a deeply contradictory relationship to social progress. On the one hand, capitalist modes of production and exchange emerged in the interstices of a patriarchal feudal system in Western Europe and gradually weakened traditional forms of authority based largely on inherited status. The expansion of competitive markets created incentives for innovation, and new forms of labor discipline contributed to the expansion of low- 
price commodity production. Capitalism, as its defenders emphasize, has been an engine of technological change, increased productivity, and the erosion of some forms of hereditary status inequalities.

On the other hand, capitalist forms of production created a new elite capable of pursuing its own interests at the expense of society as a whole. Capitalist economic growth, highly concentrated within the nation-states where it first emerged, enabled imperial nations to colonize weaker countries and extract resources, labor, and profits from them. By the same token, colonial expansion, accompanied by military domination, slavery and debt peonage, as well as wage employment, fueled capitalist economic growth.

Because of the different historical conditions in which capitalism emerged and developed in different times and places, there have always been great variations in the concrete forms of capitalism across nations. Today, however, the many different kinds of capitalism are rapidly becoming "de-nationalized." The current era features concerted efforts to relax regulation of capitalist enterprises and expand their scope, and to roll back state interventions in the economy. Radical pro-market ideology emphasizes the virtues of competition unencumbered by concerns for human needs or social justice. Radical pro-market policy rejects progressive taxation and brandishes the putative merits of budgetary austerity to cut public spending. Economic strategy is defined on the national level by efforts to replace public provision by market-based services (including privatized pensions and school vouchers) and on the international level by increased resistance to paying taxes (such as utilization of offshore tax shelters), relocation of investment to low-wage venues, and greater reliance on global supply chains.

These dimensions of recent pro-market, anti-state tendencies complement one another. The globalization of investment makes employers less dependent on the health, education, and 
other capabilities of a national labor force, reducing the potential costs to them of cuts in social spending. Offshoring and outsourcing, as well as financial shells designed to minimize global tax liability, force countries into a bidding war to offer the most favorable business climate. These strategies increase the profitability and the power of large firms relative to both workers and their small-business competitors.

But while globalization is offering capitalism itself new stepping stones, it is also creating stumbling blocks to further expansion (see discussion in Chapter 12). If all governments underinvest in the health and education of their workforce, productivity growth is likely to decline. Capitalist employers, like everyone else, would benefit from a sustainable and healthy natural environment that minimizes the threat of disruptive climate change. Financialized capitalism, however, often devises ways to maximize profits by offloading risks. In the absence of international regulation, capitalist competition creates incentives for short-run profit-maximizing strategies that could prove catastrophic in the longer run.

Capitalist employers, like everyone else, would also benefit from a sustainable and healthy social

environment that minimizes the threat of war, terrorism, and crime. In the absence of both national and international regulation, however, market-driven inequalities in opportunities and income fuel many forms of social conflict. International migration and refugee flows are one indicator of the resulting tensions. Political backlash against both immigration and free trade is another.

As with other hierarchical systems, capitalism reproduces itself over time though a number of different mechanisms: the concentration of wealth, investment in political influence, and promotion of a specific individualistic ideology and culture. However, it also derives 
legitimacy from two other sources: the promise of delivering economic growth, and competitive dynamics that encourage political conflicts among subordinates (“divide and conquer")

Recurrent financial crises, such as those that sparked the Great Recession of 2007, have been accompanied by relatively slow growth in earnings and employment in high-income countries. Confidence that a rising tide will lift all boats is undermined when it becomes clear that many boats remain stuck in the mud. On the other hand, the political realignments now taking place in the U.S., and Western Europe seem to be contributing more to a revival of nationalism than a reform of capitalism, and they also draw to an important extent on state structures, drawing the state into the complex of financial capitalism. It remains unclear how these alignments will play out over the next decade.

\subsection{Collective conflicts based on class, gender, race and citizenship}

Popular mobilization and other forms of collective action both express an ideal of democracy and offer a potential force for progressive change. But traditional theories of popular mobilization, always susceptible to wishful thinking, seem increasingly out of date. The expectation that wage-earners bound by common economic interests in the workplace would easily join hands to restrain or even abolish capitalist prerogatives has proved simplistic. The slogan of the Occupy Movement in the U.S., "We are the 99 percent" effectively called attention to power concentrated in the hands of the top 1 percent. However, it did not enable the 99 percent to overcome their internal divisions and effectively combat increased inequality.

Class is not the only dimension of collective interests that has proven mutable. Confidence that "people of color" would always unite around a common agenda or that women 
would always pursue common gender interests has also been shaken, replaced by a new appreciation of unpredictable cycles of contingent solidarity.

Collective interests are difficult to define, much less effectively pursue, in a multi-layered global economic system where information is abundant, but difficult to organize and interpret. Strategic complexity makes prediction difficult. Optimal strategies for individuals depend in large part on those adopted by others, leading to tipping points and other non-linear dynamics (Axelrod 1997; Arthur 2013). Political mobilization is susceptible to small exogenous shocks and feedback loops that further add to unpredictability.

Collective interests themselves cannot be defined in one-dimensional terms, because people typically belong to intersecting groups that offer different levels - and different formsof privilege and disadvantage. On the one hand, a white working-class woman in the U.S. enjoys substantial benefits from her citizenship and her race, but pays certain costs related to her gender and her class. She is embedded in a matrix of group memberships to which even more variables, such as religion, sexuality, marital status, and physical appearance could be added.

An explicit theory of "intersectionality" grew out of the criticisms that black and ThirdWorld feminists leveled at feminist theories which largely ignored significant differences among women based on race, ethnicity, and citizenship (Crenshaw 1989). But the concept of intersectionality has important antecedents. Karl Marx described the ordinary English worker of his day in these terms: "In relation to the Irish worker he feels himself a member of the ruling nation and so turns himself into a tool of the aristocrats and capitalist of his country against 
Ireland, thus strengthening their domination over himself ... his attitude towards him is much the same as that of the "poor whites' to the 'niggers' in the former slave states of the U.S.A."6

Similarly, theories of a "comprador bourgeoisie" pursuing its class interests at the expense of contributions to national economic development and splits between the center and the periphery of the global capitalist system explicitly invoke intersectional complexities (Frank 1967). Another interesting antecedent emerges from research on contradictory class locations in the U.S., an approach that emphasizes implications for political mobilization (Wright 1998). Intersectional theory is sometimes equated with "identity politics," a term often used describe political movements that focus on a particular dimension of collective identity, such as race, gender, or sexuality. This term is accurate, insofar as it emphasizes the extent to which individuals may or may not identify with others who they perceive as similar. However, "identity politics" is often contrasted with politics based on "economic justice" as though identity politics rests entirely on a cultural and political, rather than economic footing, or as though economic interests are synonymous with class interests.

This contrast is misleading. Mobilization around economic interests requires identification with at least some fellow interest-holders (in some instances, known as class consciousness). Collective action based on group identities such as race, gender and citizenship is often motivated by economic interests and has specific economic consequences. Intersectional analysis can be taken to extremes, denying the existence of categories such as "women" or "class." On the other hand, it can also help progressive coalitions develop unified strategies to turn diversity into strength.

\footnotetext{
${ }^{6}$ Karl Marx, Letter to Meyer and Vogt, cited in Jon Elster, Making Sense of Marx. New York: Cambridge University Press, 1985, p. 21.
} 
Such coalitions are particularly important given the rise of populist and in some cases proto-fascist movements around the world, which seem to reflect mobilization around privileged national and racial identities. Historical analysis of the rise of fascism in Europe in the 1920s offers important parallels between what happened then and what is happening now in the U.S., Europe, and some other countries, including India. The promise that aggressively nationalist policies will deliver significant benefits to a dominant ethnic group may be false, and it may never be realized. It offers, nonetheless, almost hypnotic appeal, in part because it typically evokes a nostalgic past of unquestioned dominance that assuages fears of the future (Paxton 2004).

The social psychology of intersectionality may also help explain this particular political alignment. Social scientists have traditionally focused on forms of political mobilization that represent collective efforts to challenge exploitation or oppression, which have certainly changed the course of history. But experimental research suggests that people are generally more eager to avoid losses than to risk gains ("loss aversion"), an asymmetry that reinforces resistance to change. Experimental research also suggests that people who belong to intersecting groups are more eager to identify with those that enjoy the higher status (Fiske 2012). In other words, a working-class white man may identify more with his race and gender than his class, because these dimensions offer him a stronger relative position and self esteem. While the concept of intersectionality clearly requires further elaboration, it helps explain why conflicting interests and divided loyalties play such an important role in political debate, and it lends weight to the more narrative accounts of the effectiveness of "divide and conquer" strategies.

Taken together, these many complexities in the formation of coherent, collective interests and solidarities constitute one of the most difficult obstacles to social progress. Social progress 
depends to a significant extent on the capacity of people to engage in collective action in pursuit of the values that constitute progress. For this to occur requires overcoming the cross-cutting interests and identities in contemporary societies, formed and fractured at different scales of social organization.

\subsection{Current limits of democracy as an obstacle to progress}

Democracy is a work in progress. But inherent to this is the recognition that some political activities ostensibly undertaken in the name of 'democracy' may actually impede social progress. In order to be progressive, 'democracy' requires continual critical vigilance. And in any case, whatever their forms, ideals of democratic governance are seldom fully achieved in practice. So, the resulting inevitable disappointments can undermine confidence in both collective decision-making and the role of the public sector in the economy. As earlier chapters of this report (particularly Chapters 9 and 14) explain, much theory and practice concerning 'democracy' now seem increasingly obsolete.

Political theory has traditionally focused on the design of constitutions aimed to provide checks and balances on majoritarian rule. But it has become increasingly clear that the analysis of political institutions cannot be separated from the analysis of economic institutions that influence the distribution of wealth and income. Not long ago, economists often described democracy as kind of luxury good that countries could not afford until they achieved affluence (Barro 1994). Today it is widely recognized that democracy contributes to forms of empowerment that both reduce inequality and promote economic growth (Acemoglu and Robinson 2012). Democracy can enhance trust, encouraging cooperation, improving health and 
education, and helping foster robust demand for new goods and services. It can help overcome ethnic inequalities and foster effective provision of public goods and regulation of public 'bads.'

Unfortunately, the trajectory of social and economic change threatens to both intensify ethnic conflict and undermine democracy. Global competition undermines cooperation (Chua 2004). Political investments give the wealthy disproportionate influence. In the affluent nations, increased inequality among voters leads to a greater divergence of interests, intensifying distributional conflicts that are often destabilizing as well as unproductive. The immediate symptoms include declining voter turnout, disengagement from existing political parties, and lack of trust and cooperation in governance.

International inequalities are also relevant, contributing to horrific military conflicts, refugee crises, and persistent underdevelopment and poverty in some areas of the world. All these factors have fueled a conflagration of systematic terrorist activities, with profoundly frightening and demoralizing effects around the world. Efforts to respond to terrorist threats have provoked many states to seize new, intrusive police powers for monitoring and interrogating residents.

The largely unregulated accumulation and concentration of global wealth creates enormous potential for corruption of democratic processes through campaign finance contributions, manipulation of mass media and revolving doors between government regulatory agencies and the private sector. As Arundhati Roy puts it, "Free elections, a free press, and an independent judiciary mean little when the free market has reduced them to commodities available on sale to the highest bidder" (2004: 55).

Low-income countries and even low-income regions within rich countries are forced into bidding wars, where those that offer the most generous subsidy and least regulation of corporate 
investments are the winners. ${ }^{7}$ The diminished economic significance of national borders has drastically reduced the efficacy of national government, a point that is widely, but rather helplessly acknowledged. The journalist William Grieder pointed to the increased disjuncture between global capitalism and national government in his 1997 book, One World, Ready or Not, and a question he asked twenty years ago has become even more relevant today: "If capitalism is now truly global, what are the global social obligations that accompany it?" (1997: 334).

From a libertarian perspective, the answer to that question is "none." The liberal tradition has typically pictured democracy as a set of rights, with hardly a mention of the word “obligation.” Threats such as cataclysmic climate change and nuclear war dramatize the limitations of this approach. Future inhabitants of the planet do not have a vote; they are represented only through our concern for them. The feminist theorist Joan Tronto makes a case for centering democratic politics on responsibilities for care and ensuring that "democratic citizens are as capable as possible of participating in this assignment of responsibilities " (2013: $\mathrm{xv})$.

Existing national democracies are unlikely to take on such a task, and the most powerful and affluent countries in the world exercise disproportionate international influence through completely undemocratic institutions such as the World Bank and the International Monetary Fund. More representative institutions such as the United Nations remain relatively powerless. The United Nations General Assembly set up a commission to propose important global

\footnotetext{
${ }^{7}$ See, for instance, David Barboza, "How China Built Iphone City," New York Times, December 29, 2016, available at http://www.nytimes.com/2016/12/29/technology/apple-iphone-china-foxconn.html
} 
economic and financial reforms, but its recommendations fell on deaf ears. ${ }^{8}$ The outcome of UN deliberations in Addis Ababa in 2015 on Financing for Development was similar. Developing countries asked for a global tax regulatory body to be created under the auspices of the UN, but developed countries bulldozed the idea, insisting that global tax matters be left to the OECD. ${ }^{9}$

Units of democratic decision-making must be enlarged. At the same time, they must also be extended downward. The narrow confinement of democracy to a political sphere of limited relevance to most people's lives has contributed to a cynical professionalization of government and increase in bureaucratic passivity. The public sector of the economy is indispensable to the provision of health, education, and social services, as well as other public goods. Its centralized and hierarchical administration, however, has often fostered hostility and resentment. The punitive, carceral side of the state is often the most visible one. Given a choice between "the market" and "the state" many citizens remain ambivalent and undecided, creating wide political openings for coordinated efforts to privatize public services.

Citizens who lack opportunities to develop the skills required for collective decisionmaking and management on a daily basis may not be able to effectively maintain political democracies. Efforts to develop more cooperative economic institutions, whether described as "shared capitalism" or as "democratic socialism," could both reduce inequality and improve capabilities for conflict resolution. The future of democracy itself hangs on its extension beyond the political to the economic realm.

\subsection{Social science as an obstacle to progress}

\footnotetext{
${ }^{8}$ See http://www.un.org/ga/econcrisissummit/docs/FinalReport

${ }^{9}$ See the UN report at http://www.un.org/esa/ffd/wp-content/uploads/2015/08/AAAA_Outcome.pdf
} 
We are at a crossroads at which it is urgent to defend not only the social sciences in themselves, but also their insights into possibilities for building a better world. Many worrisome trends, including the recent persecution of over 250 academics in Turkey (the signatories of Academics for Peace), have shown that fascism and authoritarianism are not a thing of the past. Strong political forces today are ready to sideline the inconvenient contributions of both the social and the natural sciences. Faced with this threat, some scholars in some disciplines have begun the difficult exercise of reconsidering yet again their relationship to power, and some have also raised voices of collective protest. What will be the role of social science for the coming era? Will it be one of active contribution, hibernation, or resistance?

Social scientists are, in general terms, sharply divided along both inter- and intradisciplinary lines, and our differences of opinion both reflect and shape deep political divisions. The IPSP is an effort in consensus building, and represents what might be called a progressive consensus among social scientists. Nonetheless, it is worth noting that the social sciences themselves can also create significant obstacles to progress.

In our view four specific problems stand out. First, there is the continuing dominance of social science originating in and reflecting the perspective of the Global North. This derives from several sources, including resource inequalities, Anglophone hegemony in publishing and related activities and also colonial, neo-colonial, imperialist and neo-imperialist legacies and practices (Graham et al. 2011), as part of the broader global division of labor of research infrastructure, libraries, data banks and research centers (Hountondji 1997; Connell 2014). ${ }^{10}$ This is important not only in terms of substantive research analyses and specific research topics and priorities, but also more broadly for epistemology, ontology and knowledge constructions (Santos 2014).

\footnotetext{
${ }^{10}$ See http://geography.oii.ox.ac.uk/?page=the-location-of-academic-knowledge
} 
Postcolonial scholarship, now well developed in and across some disciplines, recognizes the limitations of analyses that are derived only from the global North. ${ }^{11}$ In addressing the global political organization of research, the Beninese philosopher Paulin Hountondji (1997) has analyzed the historical practices of science whereby the global periphery has supplied data, and then later applied science from the metropole in practical ways. He also makes the stronger case for less external orientation that seeks legitimation of knowledge from the global North on the part of global Southern researchers. These issues are also very much part of debates on transforming the postcolonial condition in Africa and elsewhere (Mbembe 2001). What might be suggested by such work is that global Southern- and global Northern-based research and researchers should find better, less colonialist or imperialist ways of working, as in 'mutual learning across boundaries. ${ }^{12}$ Developing a truly global social science of knowledge and knowledge construction is an aspiration in process (Connell et al. 2017).

Second, and in some ways related to the first, a tendency toward narrow professionalism and specialization has discouraged efforts to communicate with a larger public and contribute to the development of public policy. In current debates on development policies, observations that are not based on stylized — and often problematic—-randomized control trials are often discounted. Increased competition for university jobs and emphasis on publication in academic journals has reduced the support and respect once offered to "public intellectuals." At the same time, the increasingly precarious character of the academic job market (along with that for journalism) means that scholars lack the institutional stability required for the process of

\footnotetext{
${ }^{11}$ These issues are very much on international agendas, for example, the initiative of the International Sociological Association on the Global Dialogue online journal series (http://isa-global-dialogue.net/) See also Bhambra and de Sousa Santos, 2017.

${ }^{12}$ We are grateful to Kopano Ratele for this clarification.
} 
knowledge creation. Such precarity undermines the capacity of the academy to defend itself against political intrusion. Further, social scientists are now operating in an information environment dominated by oligopolies such as Google, even as new social actors proliferate information that is either unverifiable or not exposed to scrutiny.

A third problem concerns a failure to reinforce the importance of scientific inquiry and standards of evidence in policy debate, leaving public discourse increasingly vulnerable to ideological bias and media manipulation. Some social scientists cling to positivist convictions that prevent them from expressing an opinion on political issues when irrefutable empirical evidence is not available. At the opposite extreme, some embrace a post-modernist skepticism that challenges any distinction between truth and falsehood. Social scientists need to carve a wider path between "everything true is measurable" and "nothing is true." As E. P. Thompson (1978) put it, the facts are there not to disclose their own meaning, but to "be interrogated by minds trained in the discipline of attentive disbelief" (1978: 29).

A fourth problem of social science needs particularly serious inquiry—its frequent deployment on behalf of the powers that be. One vivid example is provided by the American Psychological Association's support for psychologists' involvement in U.S. military interrogations, which raises serious ethical questions (Pope 2015). Another example is provided by the neoclassical economic "proof" that unfettered market forces lead to efficient outcomes. While not all economists by any means endorse this view of the market (the otherwise correct mathematical result relies on many assumptions that are not realized in practice), this assertion undergirds the implementation of radical pro-market policies on a global level and encourages disregard for environmental sustainability. Although it is confined to efficiency analysis, it also bizarrely serves to validate the existing distribution of power and income. In defense of 
individuals in the top one percent, Harvard economist Gregory Mankiw explains the standard neoclassical economic framework as follows: "The rich earn higher incomes because they contribute more to society than others do " (2013: 29). Similarly, economist Tyler Cowen's (2013) recent book, Average is Over, celebrates the claim that market forces increasingly reward excellence and innovation. These propositions are based on spurious assumptions that inherited advantages, power and networks play no significant role within capital and labor markets. ${ }^{13}$ The inordinate influence on policy-making, at both the national and international levels, of economists and ill-trained business executives who broadly accept this ideological interpretation of economic theory undermines the potential for social science to contribute to social progress.

\section{Overcoming Obstacles}

The obstacles to sustainable social progress - progress that is robust and continues into the future - are enormous in the world today and the prospects for overcoming those obstacles seem daunting (See discussion in Chapter 8). What is more, there is real urgency in the need to overcome these obstacles. Just muddling through does not seem a viable option. Even if the apocalyptic visions of some environmentalists are overstated, unless there are significant changes in the direction we are collectively moving, global warming and climate disruption will generate enormous suffering and destructive conflict. Disastrous effects, concentrated in the poorer parts of the world least able to cope, will cause demographic pressures from escalating flows of refugees, including future climate refugees, putting tremendous strains on host countries.

\footnotetext{
${ }^{13}$ Labor markets are imperfect and incomplete because workers do not choose their initial endowments of capital or skill and are vulnerable to many outside forces that they cannot possibly anticipate. Even in the absence of explicit interference with market outcomes, many forms of power shape wage determination.
} 
Increasing economic marginalization and precariousness for significant parts of the population within both rich and poor countries, combined with increasing concentrations of wealth and power, will further undermine democratic institutions. Personal, family and community life will be profoundly disrupted.

The long-term consequence of simply trying to muddle through is likely to be social regress on many dimensions, not progress. These tendencies are all complicated by trends in science and technology, including the advance of biotechnologies, automation, and artificial intelligence, which may intensify existing inequalities.

We need to mitigate, if not overcome, social divisions by developing a persuasive vision of a more collaborative, democratic and egalitarian society.

The proposals and initiatives most relevant for promoting social progress would obviously vary enormously depending both on political context and a wide range of socioeconomic factors. We will not attempt to map out these variations here. We will also not attempt to lay out a comprehensive institutional design for an alternative socio-economic system. What we can do is give some sense of the kinds of proposals that reflect this broad strategic vision.

Proposals for new institutions can be evaluated on three principal grounds: their desirability, their viability, and their achievability. Desirability refers to the extent to which proposals embody desirable values. In our discussion, here we emphasize the values of democracy, equality and solidarity, but certainly other values would be relevant as well. Viability refers to the extent to which a proposal, if instituted, would in fact generate in a sustainable way the anticipated desirable consequences. In particular, some proposals may look very good "on paper," but if instituted would have self-destructive, perverse side effects. This was at least part of the problem with the idea of socialism as comprehensive, central planning of entire 
economies. Finally, achievability refers to the extent to which we can get from here to there. In particular, for many kinds of proposals, this means assembling the social forces and collective actions needed politically to implement a proposal. In some ways, this is the most problematic of the three criteria, for while it may be possible to make sensible claims about what sorts of political forces can be mobilized for social change in the immediate contexts of the present, it is extremely hard to say anything very precise about what might be possible even a few decades in the future; there simply are too many contingencies and unknowns about the nature of crises and particular concatenations of events that might suddenly make what seemed impossible, possible. In what follows, therefore, we will stress the desirability and viability of various proposals, rather than their achievability. In any case, one of the things that may contribute to the achievability of social progress are arguments about the desirability and practical viability of different proposals.

\subsection{Transcending the economic structure of capitalism ${ }^{14}$}

At the heart of any plausible vision of constraining and eventually displacing capitalism as the dominant form of economic organization in a modern economy are three broad kinds of initiatives.

First, displacing the dominance of capitalist organizations requires expanding noncapitalist forms of market activity. While markets may be an essential feature of any viable

\footnotetext{
${ }^{14}$ We use the specific term "capitalism" here, rather than the more encompassing term "market economy" for several reasons: (1) Not all market economies are capitalist; capitalism is a particular form of organization within the market economy. (2) The term capitalism points to the role of political and economic power in the economy rather than simply the "site" of economic transactions. (3) In any case, it is a misnomer to describe contemporary economies as simply "market economies" since the public sector constitutes a substantial share of both employment and output, and unpaid work accounts for about half of all labor time.
} 
complex economy, markets need not be dominated by capitalist firms, capitalist investment, and capitalist rules. A "cooperative market economy" is one alternative way of organizing marketoriented production. A variety of non-capitalist types of firms could populate such an economy: worker cooperatives; employee stock owned firms; community-owned firms; hybrids of various sorts; individual proprietorships. And these firms could interact under rules which dampen competition and foster cooperation among cooperatives, for instance on providing employment security to workers, without encouraging collusion against customers.

Second, instead of a "market-conforming democracy," we can imagine new institutional devices to create a "democracy-conforming market." ${ }^{15}$ Vigorous, effective, democraticallyimposed regulations on the market and on the strategies of capitalist firms are needed to ensure that they serve the broad interests of people. This should include redistributive tax-and-transfer policies that would significantly reduce the destructive economic inequalities generated by under-regulated competition, as well as new mechanisms through which democraticallydetermined priorities could shape the allocation of investments for different social objectives. Such policies would necessarily require interference with the unfettered private exercise of power by owners of capital and managers of firms. Of particular importance in the current era would be new forms of effective democratic regulation of finance designed to both reduce the power of finance and reduce the systemic risks posed by financialized capitalism. While such democratic regulation of capitalism may also help to stabilize capitalism, it nevertheless renders it less purely capitalistic.

\footnotetext{
${ }^{15}$ The expression "Market-conforming democracy," comes from Angela Merkel. The expression functions much like Margaret Thatcher's well-known "There is no alternative" to suggest that a capitalist market economy constitutes a hard constraint on society. From this perspective, democracy should not try to subordinate the market to collectively decided priorities; such efforts are doomed to fail.
} 
Third, we need to expand decisively the direct role of the state or community in meeting human needs. One of the hallmarks of the recent era in policy-making is the idea that the market, particularly the market dominated by profit-motivated private firms, generally provides the optimal way of meeting virtually all human needs. This claim has underwritten the privatization of state services and the general decline in the support for the state's role in creating a broad array of public goods and services. The provision of an expansive set of non-commodified, publicly-provided goods and services is critical for social progress. This includes the typical services closely tied to caregiving and social reproduction: early childcare services; eldercare and disability care services; health and education. But it also concerns a range of public amenities that enable people to engage in non-capitalist economic activities: community centers; performance spaces for non-commercial arts; makerspaces and fablabs (facilities where people share various arrays of machines for individual and collective projects); meeting rooms for public events; spaces for social and solidarity economy activities.

What follows are a series of more specific proposals for each of these three ways of transforming capitalism.

\section{Building a Vibrant Cooperative Market Sector}

The idea of "cooperatives" includes a rather heterogeneous set of economic organizations: consumer cooperatives, owned by consumers, and generally indirectly governed by consumers who elect the board of directors; credit cooperatives (typically called credit unions), formally governed by their members; producer cooperatives, owned and governed by privately-owned firms which join together for purposes of distribution and marketing; housing cooperatives, including communal housing, co-housing, and various other forms; solidarity 
cooperatives, governed by elected boards of stakeholders; and worker-owned cooperatives, owned by workers and governed on a one-person-one-vote basis. All of these are relevant to building a cooperative market economy.

Within this array of cooperative forms, worker-owned cooperatives are especially important in imagining a future in which capitalism no longer dominates economic life and in which the heart of the economic system is organized on the basis of democratic, egalitarian and solidaristic principles. Two issues are at play here. First, worker cooperatives constitute a direct transformation of the social relations within firms. Workers are now owners, elect the management of firms on an egalitarian one-person-one-vote basis, control the surpluses generated by the firm and are involved in setting the basic strategic priorities of firms. While worker cooperatives generally produce for the market, they are organized around values very different from capitalist firms: solidarity, equality, democratic governance, dignity of work, community development. To the extent that the firms that populate a market are organized in this way, that market will be less capitalistic.

Still, worker cooperatives are producing for a market and thus are competing with other firms, and such competition imposes external constraints on their priorities. Like all marketoriented firms, worker-cooperatives need to make profits to stay alive, and won't this simply lead them to behave like capitalist firms? Won't they still set investment priorities based on selfinterested profits, ignoring issues of positive or negative externalities or other social objectives? As Paul Samuelson [1957] once claimed, “it doesn't really matter who hires whom: so have labor hire capital" [1957: 894] - will worker-owned firms still behave the same way?

This brings us to the second way that worker cooperatives could play a critical role in an overall democratization of the economy. Two of the central obstacles to effective democratic 
regulation of capitalist markets are the concentration of power of wealthy owners of capitalist corporations and the ease of capital mobility to escape regulation. Both of these obstacles are significantly reduced with worker-owned cooperatives. Worker-owners, even in highly successful cooperatives, will not accumulate the fortunes that would enable them to wield the kind of political power that owners of capitalist corporations do. Perhaps even more significantly, worker cooperatives are rooted in particular places. Such firms constitute geographical anchors for investment, thus rendering capital less footloose. This makes them intrinsically easier to regulate. Thus, even though the firms of a cooperative market economy would still be profit-oriented, a cooperative market economy would more easily be subordinated to democratically determined priorities. Unlike markets dominated by capitalist firms, it would be a democracy-conforming market.

In existing capitalist economies, worker-cooperatives generally occupy relatively marginal niches within the overall economic ecosystem and generally do not figure as central components of the political programs of anti-capitalist movements. This was not always the case. At times in the nineteenth century, there were significant currents within anti-capitalist movements that saw cooperatives as potentially replacing capitalism altogether. This was at the heart of the famous debate between Proudhon and Marx. At a minimum, cooperativists hoped that even if worker cooperatives did not displace capitalist firms entirely, they could nevertheless eventually constitute a significant sector within market economies, offering workers an alternative to capitalist employment. Marx was skeptical that worker cooperatives could ever reach a scale to challenge capitalism, though in the course of his life he became much more appreciative of the symbolic value of cooperatives as a visible demonstration that workers didn't 
need capitalists. The historical record is much more consistent with Marx's prediction than Proudhon's vision.

The relative marginality of worker-owned firms in contemporary capitalist economies poses a serious puzzle: if worker cooperatives in fact offer a desirable alternative to capitalist employment, why are they largely confined to niches on the margins of contemporary economies? Some people argue that the transaction costs of running a firm democratically place them at a competitive disadvantage once a firm gets above a relatively small size, both because the tasks of running the firm become more complex and because the labor force of the firm becomes more heterogeneous, making decision-making more difficult (Hansmann 2000). Others argue that the understandable risk-aversion of workers means that few are willing to put whatever savings they have into a cooperative. Furthermore, when worker cooperatives do become successful, there is a strong temptation for the original members of the firm to begin hiring employees and ultimately convert the firm to an ordinary capitalist enterprise.

Supporters of worker cooperatives argue that the existing empirical distribution of capitalist and non-capitalist firms in the market is heavily conditioned by the nature of the institutional environment in which firms are incubated, developed, and sustained. Credit markets, government programs to encourage local economic development, and management training programs in universities, are all heavily oriented to ordinary capitalist firms. We simply don't know what the potential economic space for worker cooperatives, as well as the broader array of cooperatives, would look like if public policy were systematically oriented towards fostering a cooperative market economy. A number of changes in the rules of the game could facilitate the building of a cooperative market economy: 
1. Conversions of capitalist firms into cooperatives. The conversion of existing capitalist firms into cooperatives is especially relevant in contexts where small-to-medium sized enterprises are owned by a family in which no adult children are interested in running the firm and thus there is a succession problem when the existing owner dies or wishes to retire. Straightforward worker buy-outs are generally difficult, since workers lack the capital for such an investment, and even if they can get loans from the ordinary credit market, this is likely to create a debt burden on the firm that would undermine its viability for the future. A public policy to subsidize the conversion of firms into worker cooperatives could remove this obstacle. In the United States today, there already exists a mechanism, called an ESOP (employee stock ownership plan), which facilitates employees owning some or all of the stock in a capitalist firm. Such firms are still governed by a one-share-one-vote principle, so generally management has much more voting power than ordinary workers, and in any case in most ESOPs employees own only a minority of the shares. If the democratic governance of firms were seen as an important value, then there could be additional subsidies to underwrite the conversion of firms into fully democratic cooperatives.

2. Worker take-overs of firms in contexts of bankruptcy. In various places around the world, workers have taken over enterprises when those enterprises are facing bankruptcy. In recent years, the most striking instance of such worker take-overs were the empresas recuperadas (recovered enterprises) in Argentina, beginning in the severe financial crisis of 2001, but continuing afterwards during the economic recovery as well. Several hundred firms were occupied by their employees, who continued to operate the firms, producing goods and services for the market. These firms were generally terribly undercapitalized, and in the 
conditions of the crisis it was difficult for the workers running the firms to get needed capital from any source (Itzigsohn and Rebón 2016; Rebón 2007). Nevertheless, many survived.

Worker take-overs of enterprises typically occur under desperate conditions, hardly the optimal situation for creating worker cooperatives. Nevertheless, there are a number of public policies which could be used in these cases which could significantly facilitate the conversion of failing capitalist firms into worker cooperatives. Bankruptcy laws could be changed to give the workers in a firm the right to state-supported buy-outs with favorable loans and grants from the state. In cases where enterprises are abandoned by their owners - as was the case in the Argentinian crisis -- the right of eminent domain could be used to initially transfer property rights to the state (Rannis 2016). This would create the breathing room needed to plan a proper conversion.

\section{Management training and a technical support for cooperatives. Management of} cooperative enterprises is not the same as management of ordinary firms. One of the reasons why the cooperatives in the Mondragon cooperative group in Spain have been so successful is the existence of systematic programs for training people in how to work in and manage cooperative firms. The Mondragon group also has a range of research and technical support organizations to help individual cooperatives with various planning and innovation tasks. These organizations are themselves organized as cooperatives. The result is a dense network of specialized cooperatives in the service of the Mondragon cooperative market economy. In order to facilitate the development and sustainability of a cooperative market sector, the state needs to play a role in developing comparable institutions elsewhere. 
4. Credit institutions for a cooperative market. Credit markets are not well-suited for a cooperative market sector. The risk profile of small firms in general makes it difficult for them to get loans, but this is especially the case for worker owned firms. Subsidized access to capital both in the form of credit and grants - is essential if there is to be a vibrant cooperative market sector and eventually cooperative market economy. An objection to such subsidy is that it would give cooperatives an "unfair" advantage over conventional capitalist firms in market competition. Once it is recognized that enhanced democracy is a positive externality of cooperatives and a cooperative market economy is a key part of a more democratic economy, then a significantly subsidized credit market specifically designed for cooperatives is justified.

\section{Democratizing the large capitalist corporation}

It is well and good to imagine a more democratic economy with a substantial sector organized through cooperatives of various sorts. But worker-owned cooperatives are nearly always very small firms. Even the largest industrial cooperatives in the Mondragon group have only a few thousand members. Can one really imagine General Motors or Exxon being organized as a worker owned cooperative? The large corporation owned by outside investors is at the very heart of the capitalist economy. What would it mean to "democratize" the large multinational corporation?

Isabelle Ferreras has proposed an institutional design for governing the capitalist firm that answers this question (Ferreras 2017). She calls the model "Economic Bicameralism." She develops the idea through an analogy with the development of bicameral legislatures in the early modern state. A stylized characterization of the development of British parliamentary democracy would note that the premodern state consisted of a king in political dialogue with a chamber of 
great landed magnates. In the late fourteenth century a second chamber, the House of Commons, was added, although it took several more centuries before this rudimentary form developed into a fully-empowered bicameral parliamentary democracy. This two-house parliament, in Ferreras's words, "expresses a dualist ontology of society with landowners on one side and the people (or at least their representatives) on the other."

Now think of the modern corporation. The largest of these firms generate more income annually than most countries in the world. They have a chief executive officer, analogous to a king, who is accountable to a chamber of wealthy investors, analogous to the House of Lords. These massive organizations are political entities in so far as they have the capacity to command massive resources for various purposes and control the activities of tens of thousands of people. And yet the ruler of such organizations is only accountable to one kind of person: the investors of capital. Ferreras proposes the creation of a second chamber of the board of directors representing the investors of labor in the firm. This "House of Labor Investors" would have coequal powers to the "House of Capital Investors" creating the kind of balance of power found bicameral parliamentary systems:

The essential - and sought-after - effect of economic bicameralism is to allow all of the firm's investors, through the representatives they elected to the Capital and Labor Investors' Chambers, to participate in decisions about all issues affecting the life of the firm, without exception ... . That both Chambers must participate in all decisions should be reiterated here: reserving certain issues for one Chamber alone would create an incomplete form of bicameralism, and reproduce the power imbalances that characterize firms' current unicameral system, which has caused the illegitimate, unreasonable and

\footnotetext{
${ }^{16}$ Ferreras Manuscript, p.83. [pages in published book will be provided when available in early fall 2017]
} 
unintelligent governance now all too common in the contemporary business world, with the dire consequences we know today. ${ }^{17}$

A corporation with a bicameral governance structure would still produce for the market and would still have to contend with competitive pressures, but it would no longer be governed by the single imperative of maximizing the returns on capital invested. It would be a hybrid form forced to seek compromises between the priorities of capital investors and those of labor investors in the firm.

\section{Unconditional Basic Income ${ }^{18}$}

Unconditional basic income (UBI) is a proposal to give every legal resident of a territory an income sufficient to live above the poverty line without any work requirement or other conditions. Taxes are raised to pay for the UBI, so even though everyone gets the income, highincome earners would be net contributors (their increases in taxes would be larger than the UBI they receive). Existing public programs of income support would be eliminated, except for those connected to special needs (e.g. disabilities that require extra income). Minimum wage laws would also be eliminated since there would no longer be any reason to prohibit low-wage voluntary contracts once a person's basic needs are not contingent on that wage. The UBI for children would be calibrated at some appropriate level compared to that for adults.

UBI opens up a wide array of new possibilities for people. It guarantees that any young person can do an unpaid internship, not just those who have affluent parents who are prepared to subsidize them. Market oriented worker cooperatives would become much more viable since

\footnotetext{
${ }^{17}$ Ferreras manuscript, p.90-91. [pages in published book will be provided when available]

${ }^{18}$ See Van Parijs and Vanderborborgt (2017) for a detailed discussion of the arguments for and against unconditional basic income.
} 
meeting the basic needs of the worker-owners would not depend on the income generated by the enterprise. This also means worker cooperatives would be better credit risks to banks, making it easier for cooperatives to get loans. UBI would constitute a massive transfer of resources to the arts, enabling people to opt for a life centered around creative activity rather than marketgenerated income. The social and solidarity economy would be invigorated, including new forms of caregiving cooperatives. UBI would also be a way of supporting people who provide carework for family members outside of the market. UBI, if it could be instituted at a relatively generous level, would move us significantly towards the egalitarian principle of giving everyone equal access to the material conditions to live a flourishing life. ${ }^{19}$

Most defenses of UBI revolve around ways in which a basic income would eliminate poverty and reduce inequality. These are, of course, important issues. Insofar as UBI reduces poverty it would itself directly contribute to social progress. But in the present context, there is an additional important consequence of UBI for social progress: in a world with UBI people can much more easily choose to engage in initiatives to build new forms of economic and social relations. ${ }^{20}$ Insofar as social progress depends on the creativity and energy of activism in civil society, UBI would increase the capacity of people to dedicate themselves to these goals.

Unconditional basic income is not simply a proposal for rich countries that already have expansive programs of income redistribution. Because the standard of living that would be

\footnotetext{
${ }^{19}$ It is important to stress that UBI by itself is not a cure-all for all of the social impediments to human flourishing in contemporary society. For example, people also have needs for meaningful productive activities, and there is no guarantee that a UBI would expand the opportunities for this. What UBI would accomplish is a more favorable economic terrain for efforts at expanding such opportunities.

${ }^{20}$ While a generous, above poverty-level basic income has the potential to open up new dynamic possibilities for non-capitalist economic development, there are also libertarian proposals which advocate introducing a basic income and then scrapping not only existing income support programs, but also virtually all public provision of services to meet human needs (i.e. education, health care, etc.). People would then have to purchase these services on the market without further subsidy. The best known advocate this position is Charles Murray (2006).
} 
considered a dignified minimum is much lower in poor countries, the actual cost of a meaningful UBI would not necessarily take a larger share of national income. A basic income that would be below a culturally acceptable level in a rich country could still make a tremendous difference in the lives and opportunities of people in poor countries. Indeed, because households in poor countries often involve much wider kin networks, even if the individual BI is small, there is the possibility of pooling basic incomes to generate significant collective assets for the household. There is at least some evidence from basic income experiments in the global south that this happens. $^{21}$

There are, of course, many objections to unconditional basic income, even by people who might share its egalitarian objectives. Three issues stand out. First there is the practical problem of affordability: is it really possible to give everyone, unconditionally, a stipend above the poverty line? While there are many technical difficulties in answering this question, in those countries with a highly developed redistributive welfare state it is already the case that through a patchwork of programs -- means tested income transfers, unemployment payments, disability payments, Social security, child allowances, and so on - poverty is nearly eliminated. A generous UBI would eliminate most of these income support programs and would be administratively much cheaper, since it virtually eliminates monitoring costs. This means that in an already generous welfare state, most people would not experience a dramatic increase in their tax payments.

The second objection is that UBI is unfair to employed, hardworking people: a recipient of a basic income who then refuses to contribute to society is being supported by those who do.

\footnotetext{
${ }^{21}$ For a discussion of an extensive basic income in India, see Davala, et al. (2015).
} 
Some form of reciprocity is a very strong normative principle. While there are sophisticated arguments by philosophers about why it is just for "surfers to be fed" (to use a metaphor of Philippe van Parijs), nevertheless many - perhaps most - people are likely to feel strongly that recipients of basic income should be required to contribute something to society (Atkinson 2015). This need not take the form of working in the market for pay - unpaid carework for family members would count as a contribution to society as would all sorts of other forms of unpaid volunteer activity. But many people might regard a person who is supported by UBI and makes no contribution as a parasite. Should the making of such a contribution be monitored? Would this undermine the principle of UBI that people should be enabled to find their own way to contribute? There are always trade-offs in any social policy, and defenders of the reciprocity principle may still decide on practical grounds as well as principle that reciprocity-enforcement is not worth the cost. Whether or not support for a UBI would be sustained over time would then depend, in part, on the number of people who violate norms of reciprocity.

A final objection sometimes raised against UBI is that it is a highly individualistic policy, enhancing the freedom of many people to make separate choices about their lives, but doing nothing to foster conditions for solidarity and community, so critical for human flourishing. Indeed, by not requiring any contribution from recipients, UBI could further undermine the values of caring and reciprocity that are already precarious in highly competitive, individualistic market economies. It is just as plausible, however, that by giving individuals more autonomy and control over their life plans, UBI would foster not just the ability, but the willingness of many people to leave the competitive individualism of the capitalist labor market to participate in collaborative socially-constructive projects of all sorts. 


\section{Universal care services}

To live, people need not only need money and the goods money can buy. They also need care, that is, help with the activities of everyday living that many people can do for themselves for much of their lives, but may need help to do when they are young, disabled or becoming frail as they age. While UBI would give everyone enough money to cover their material needs, it does not give them the care they may also need. This leaves a huge source of inequality in terms of peoples' ability to live a fulfilled life. It is a lottery who has care needs, and among them who has the resources to buy care on the market, or the family and friends willing to devote time to their care.

The need for care also generates huge inequalities between those who devote time to the care of others and those who do not. Since gender norms tend to allocate care responsibilities primarily to women, this inequality is a gendered one, which UBI would also not tackle. UBI would liberate people without care responsibilities to do worthwhile and creative things. However, for those with full-time care responsibilities, UBI would give them something to live on, but not the opportunity to do anything else with their lives.

A proposal that would tackle this problem is a Universal Care Service (UCS), free at the point of need. This is could be a complement to UBI, but is also a standalone proposal. It would give high quality care to everyone who needs it, rectifying inequalities in the life chances of both those who need care and those who take responsibility for their care.

Of course, much unpaid informal care would still go on. The giving and receiving of care is one of those spaces in which people escape those pressures of capitalism to turn every minute into money. It is a positive activity, provided the care is of high quality, willingly given and does not put obstacles in the way of a fulfilling life for both care receiver and care giver. The problem 
arises when the demands on care-givers are very high and leave them with time to do little else. Society should share the responsibility for care, by providing a UCS.

It could be argued that, rather than providing care directly, it would be better to provide those with care needs, or for children their parents, with extra money to buy their own care. The problem with this proposal is that care provided by for-profit firms tends to be of poor quality. This is because the dynamic of competition requires firms to continually seek to cut costs, unless they can offer better quality than their competitors. However, good quality care is notoriously difficult to judge because it depends so much on unquantifiable, and often unobservable, aspects of the relationship between care workers and their clients. Further, purchasers tend to be income constrained. These factors together result in a market in which competition tends to be over costs not quality. But care is a highly labor intensive activity, so the only way to cut costs is to cut staff or hire cheaper less well qualified staff, both of which reduce the quality of care provided.

Better quality care therefore tends to be provided by those who work directly in the public or voluntary sectors, where profit making is not the goal. A UCS delivered by these sectors could be more than a service for those who currently need care, but a focal point for communities.

For example, family centers could not only provide childcare, but offer opportunities for families to meet, older children to play after school and parents and others to learn skills to help them get more out of their lives. In England, there are Sure Start centers in the most deprived areas, which provide childcare as well help and advice on child and family health, parenting, training and employment. Although the funding of these centers has not been adequate to fulfil their early promise, they could, if rolled out to every community, provide the basis for a system of family centers providing universal services 
In France, many residential care homes for the elderly also provide day centers and domiciliary care services for those who need assistance in their own homes. As a result, when those who are cared for in their own homes need extra help they can move temporarily or permanently into the residential center and be cared for by staff with whom they are familiar. Such residential care homes could also become centers for the community, involving people of all ages and allowing generations to mix. Indeed, why not merge them with the family centers discussed above?

As capitalism has developed, the increased productivity of factory methods of production have rendered it more economical for households to earn the money to buy many of the necessities of life rather than produce them themselves. This has not been an uncontested process. For example, in the nineteenth century there were many protests about the adulteration of commercially bought food, contrasting the uncertainty of the quality of what could be bought in the shops with the known quality of home produced food. In the most industrialized economies of today, care is effectively the last remaining home produced good, or at least the last one that seriously limits what else people can do with their lives. But, many remain unwilling to turn care into a commodity, because the quality of care is so fundamental to people's lives and the market cannot be relied upon to produce good quality care.

But how would such a UCS be paid for? It would not be cheap, but its net cost to the state might well be a small ratio of its gross cost. This is because revenue would be raised from the increased taxes and reduced benefits of those who previously could not take employment because of caring responsibilities but now choose to do so. The exact costs will depend on the mix of types of care provided and a country's tax and benefit system, but for England it has been 
estimated that the state would recoup between $89 \%$ and $95 \%$ of the gross cost of providing universal high quality free childcare ${ }^{22}$.

\subsection{Naming and changing the powerful and the privileged}

While a key approach to social progress, neither a UBI nor a UCS necessarily addresses some wider aspects of (in)equality, privilege, and citizenship. Citizenship has historically often been framed in neutral terms, but in practice has often reproduced a male, heterosexual, raced and classed citizenry. In the light of the historical exclusion and marginalization of women, people of color, and further subordinated groupings, full citizenship requires addressing wideranging structures of inequality through policy intervention on such questions as democratic representation, work and care in and across public and private spheres.

1. Naming the powerful in institutions and policy development. Confronting inequality certainly involves pursuing egalitarian agendas, but this not only involves the inclusion of those excluded, marginalized, and subordinated. The other side of the coin is the naming the powerful, the privileged, the superordinate, those already included, as defined by age, class, ethnicity, gender or another social dimension (Pease 2010) or institutional position. Recognizing privilege is a key step in policy development, whether at the local or organizational level, in societal transformations, for example, the complex transition to post-apartheid South Africa, or in policy responses to growing concentrations of power in the hands of the largely male, transnational

\footnotetext{
${ }^{22}$ Jerome De Henau, "Costing and Funding Free Universal Childcare of High Quality, http://wbg.org.uk/wpcontent/uploads/2016/11/De_Henau_WBG_childcare_briefing3_2017_02_20-1.pdf
} 
capitalist class (Sklair 2001; Donaldson and Poynting 2006; Carroll 2010). Naming the powerful can encourage resistance to their influence.

2. Developing institutional policies and practices for changing the powerful: the case of men and masculinities. Naming the powerful and privileged can be a prelude to policy action. This applies at different institutional levels and takes many forms, for example, developing antiracist, ethnically-sensitive educational policy and workplace practices in moving towards ethnic and racial justice, anti-ageism training in working for inter-generational solidarity, or zero tolerance for bullying and harassment within institutions.

Changing men and dominant masculinities in supporting gender justice is an exemplar of policy processes directed at the more powerful. Policies for changing men and dominant masculinities have become much more widespread in recent years, and have entered mainstream agendas, such as UN, EU, Council of Europe and OSCE. For example, the EU report, The Role of Men in Gender Equality (2013), addressed policies for men's involvement in gender equality, with the promotion of caring masculinities as a central theme. Examples of such policy action include: education and training programs for less dominating and destructive forms of masculinity; promotion of men's health and healthy lifestyles; violence prevention and antiviolence work; targets and quotas limiting men's dominance in organizations; training for more egalitarian leadership and management; expanding sexuality and gender-diversity rights; promotion of men's and boys' engagement in care, paid and unpaid, family, fatherhood and reconciliation of care, home and work; changing so-called 'macho' work cultures to promote safety and reduce accidents at work. 


\section{Building transnational, inter-organizational alliances for policy development: learning}

from the global South. What is of special interest in such interventions and initiatives is that much of the most active work around men and boys is taking place in the global South, through major policy alliances. This demands new, creative, inter-organizational, transnational forms of policy development, as illustrated by the work of the global MenEngage Alliance, an umbrella organization of activists, NGOs, projects and policy actors (http://menengage.org/), on gender justice, with over 700, mainly group, members, with national networks in Africa (17), the Caribbean (5), Europe (16), Latin America (10), North America (2), South Asia (5). The Alliance's policy focus includes: gender-based violence; violence in armed conflict; caregiving and fatherhood; global political economy; sexual and reproductive health and rights; men's and boys' gender vulnerabilities and health needs; sexual exploitation; HIV and AIDS; environment and sustainability. The 2014 Delhi Declaration on men's relation to global gender justice serves as a model for changing the powerful in desirable and viable ways (http://www.menengagedilli2014.net/delhi-declaration-and-call-to-action.html); the global North can learn much from the global South. ${ }^{23}$

\section{Extending equality agendas into 'unmarked' and transnational policy arenas.}

Similarly, strategies for changing the powerful need to extend beyond policy arenas explicitly labelled as 'equal opportunities', 'gender equality' or 'diversity issues'. This means thinking of equality/inequality agendas more broadly in 'unmarked' arenas, such as trade, transport, foreign, and security policy. Thus, while policy around interpersonal violence is well recognized as part

\footnotetext{
${ }^{23}$ For further information on relevant resources, see, for example, http://www.genderjustice.org.za/, http://promundoglobal.org/, http://www.xyonline.net/
} 
of gender-aware policy, this is much less so for terrorism, racist violence, state violence, and militarism. Having said that, explicit policy on the privileged, when developed, is often framed within local or national contexts rather than transnationally, in terms of, say, global finance or the environment. Analyzing and changing policy in transnational directions demands transnational social science and policy collaborations.

\subsection{Democratizing democracy}

At the center of the idea of fighting current inequalities is the problem of democracy. This means both democratizing the power relations within the economy and deepening the democratic character of the state. These two dimensions of democratization work together: without advances in democracy within the state, it is unlikely that the necessary policies to facilitate economic democracy would be enacted; without advances in economic democracy, it is unlikely that a more deeply democratic state could be sustained.

The democratic vitality of political institutions in Western democracies has significantly eroded in recent decades. Trust in politicians and governmental institutions has declined to historic lows in many countries. In part this is due to the character of the problems democratic institutions confront: globalization and financialization of capital have undermined the autonomy and power of most national states, making it more difficult for them to effectively regulate their own economic conditions, and this in turn means that citizens have less confidence that their elected governments will be able to solve pressing problems. ${ }^{24}$ Widespread cynicism about political institutions develops from the sense that the political process and elected officials fail to

\footnotetext{
${ }^{24}$ For a strong argument that democratic states have exhausted their capacity to regulate capitalism, and as a result, democracy itself has eroded, see Wolfgang Streeck (2016).
} 
represent the interests of ordinary people. To many people, the feeling is that democracy itself is failing, not simply that the specific policies of the state need changing. What follows are two examples of institutional innovations that could contribute to a renewed, deepened democracy.

\section{Randomly selected citizen legislatures}

The ideal of democratic government is often characterized as government of the people, by the people and for the people. The standard institutional design for achieving this ideal is electoral democracy: citizens chose their political leaders through electoral competition, typically organized through political parties. The "by the people" element is supposed to be insured by elections; the "for the people" is insured by competition among politicians, so that if elected representatives fail to legislate in the interests of the people, they can be replaced in subsequent elections; and "of the people" is enabled by the principle that any citizen above a certain age can run for office. Those are the principles.

In practice, existing systems of electoral democracy fail to realize any of these ideals. While citizens certainly do vote, government by the people is blunted the role of money in elections and the structure of political parties. For the people is undermined by the multiple pressures on politicians, regardless of political ideology, to cater to the interests of elites. And of the people is blocked by the deep inequalities in the real capacities to run for office and get elected of people from different social and demographic groups. The result is that nowhere does the distribution of economic and social attributes among legislators reflect that of voters.

There are many kinds of proposals for dealing with these democratic deficits, including, among other things: changes in the rules of electoral representation; new forms of campaign financing; shifts in the responsibilities of centralized and decentralized units of government; 
changes in the way citizens get information about political choices; reserved seats for people with particular demographic characteristics; and so on. Which of these sorts of reforms would be most important for improving democracy varies from place to place. But what virtually all proposals have in common is the reliance on elections as the pivotal way that the preferences of citizens get aggregated into political representation.

There is an alternative to elections that has an ancient pedigree: selection of public officials for a legislature by random selection. This is sometimes referred to as a sortition legislature. $^{25}$ This was the way legislators were chosen in ancient Athens, albeit within very exclusionary definitions of citizens. And in many countries today, this is the way juries are selected in courts. Could random selection be adapted to legislatures in liberal democracies? And in what ways might this enhance democracy?

Here is a sketch of the design of a possible sortition legislature: The legislature would consist of two chambers. In the first, members would be elected in a conventional manner; in the second - the sortition chamber - members would consist of randomly selected citizens. Depending on the political and cultural context, the sample could be stratified on various dimensions to ensure that it reflected the salient demographic and social characteristics of the population.

The sortition chamber would have the same powers and responsibilities as the elected chamber, including budgetary authority and the opportunity to draft, debate, and vote on laws. Sortition legislators would serve sufficiently long terms to gain experience, for example fouryear terms, with one quarter being replaced each year. The pay would be generous - say twice

\footnotetext{
${ }^{25}$ For a discussion of the history of sortition legislatures, see Sintomer (2011).
} 
the median annual earnings - making the job an attractive one financially for most people. The chamber would have substantial staff support to provide initial training to newly selected sortition legislators, to organize a wide range of information services for the chamber, and to facilitate deliberation on proposed legislation (Gastil and Wright forthcoming).

There are a variety of ways in which sortition legislature would potentially deepen democracy. By enabling a sample of ordinary citizens to directly exercise legislative power, the new chamber would strengthen the idea of government "of the people," a government in which decision-makers are not recruited from elites but from the lay public. Since sortition legislators are randomly selected, they would not in any way be beholden to wealthy contributors to election campaigns. It will be easier to insulate a sortition chamber than an elected chamber from the political influence of money. The discussion of legislation within a sortition chamber is more likely than in an elected chamber to involve real deliberation, seeking common ground in the effort to solve problems.

What is more, in the sortition chamber, the selection of problems to be solved through legislation is likely to be much more in tune with the needs and difficulties of ordinary people than is the case of legislation initiated by the elected chamber. As a result, a sortition assembly is not simply "of the people;" it will also enhance "for the people."

\section{Participatory budgeting ${ }^{26}$}

A sortition legislature may embody the principle of government of the people, but by its very nature most people will not be selected. The only form of active political participation available to most people would remain voting for candidates for the elected chamber. A citizen

\footnotetext{
${ }^{26}$ Some of this discussion of participatory budgeting is taken from Erik Olin Wright (2011). See also chapter 14.
} 
observing the sortition assembly might say, it is people just like me that are making these decisions, and thus there is a kind of vicarious participation. But vicarious participation is not the same as direct participation.

There is another aspect of democratic ideals, therefore, which is missed by both elections and sortition: the idea that ordinary citizens should be able to actively participate in the direct exercise of political power, in making the decisions which affect their lives. This is sometimes referred to as "direct democracy" or "participatory democracy." Even though a core value of democracy is expressed in the idea of rule by the people, for practical reasons, the argument goes, in modern society this means rule by the freely chosen representatives of the people. The conventional wisdom is direct citizen involvement in political decisions hopelessly impractical in a complex modern society.

The development of what has come to be known as "participatory budgeting" is a sharp challenge to that conventional wisdom. Participatory budgeting was invented almost by accident in the city of Porto Alegre, Brazil, in 1989. Porto Alegre is a city of around one and a half million inhabitants in the south-east corner of the country. In late 1988, after long years of military dictatorship and a period of transition to democracy, a leftwing party -- the Workers Party (the PT) -- won the mayoral election in the city. The PT had not expected to win, but the more conservative traditional parties split the conservative vote, and the PT's candidate for mayor won with a plurality of the vote. The party, however, did not control the city council, and thus faced the prospect of having four years in office without being able to do much to advance it progressive political program.

Faced with this situation, the activists in the party asked the classic question, what is to be done? Their answer was a remarkable institutional innovation: the participatory budget. Basically 
the PT decided to create a kind of parallel city government around the city budget that could effectively neutralize the power of the city council. As in most cities with an elected mayor and city council, the mayor's office is responsible for developing a city budget and presenting it to the city council for ratification. The charter of the city of Porto Alegre, however, did not specify how the mayor was to produce the numbers in the budget. The standard procedure, of course, is for technocrats in the Mayor's office - economists, city planners, engineers - to produce the budget in consultation with politicians and various elites, but this was not mandated by the official "rules of the game." What the Mayor and the activists in the PT did, then, was create a novel budget-making system anchored in the direct participation of ordinary citizens. Initially the process was pretty chaotic, but in a spirit of democratic experimentalism, the procedures were refined over time until eventually a coherent institutional model was achieved.

Instead of the city budget being formulated from the top down, Porto Alegre was divided into regions each of which has a participatory budget assembly. There were also a number of city-wide budget assemblies on various themes of interest to the entire municipality - cultural festivals, for example, or public transportation. The mandate for each of these participatory budget assemblies was to formulate concrete budget proposals, particularly for infrastructure projects of one sort or another. Any resident of the city could participate in these assemblies and vote on the proposals. After ratifying these regional and thematic budgets, the assemblies chose delegates to participate in a city-wide budget council for a few months until a coherent, consolidated city budget was adopted.

In the years since the invention of the participatory budget in Porto Alegre, there have been hundred cities around the world in which some form of participatory budgeting has been tried. As the participatory budget idea traveled around the world it has developed into a menu of 
institutional designs rather than a single model. In many cities, the use of PB is restricted to a very narrow range of city spending, rather than the more expansive scope in the original form in Porto Alegre. In some cities, final projects are approved through a popular vote rather than by an assembly of budget delegates. In some cities, the process functioned more like a new form of patronage, controlled by political machines; in others, it contributed to popular power and mobilization. One thing is clear: it is not enough to simply adopt the formal design of participatory budgeting for it to contribute to a process of deepening democracy. What matters is how this design intersects social movements, secondary associations, and grass roots activism. But when this intersection occurs, participatory budgeting opens up an arena of direct democracy.

The proposals we have discussed, if instituted, would significantly reduce the obstacles to social progress. Many more ideas could be added to this list. If one could snap one's fingers and implement such proposals, the world would be a better place. But of course, snapping fingers won't do the trick. To overcome the obstacles to social progress requires more than good ideas about what needs to be done; it requires mobilizing the necessary social and political forces capable of translating those ideas into actual social changes. And for that, enlightenment is not enough.

\subsection{Unanswered Questions}

There are important aspects of the obstacles to social progress for which we do not know of compelling solutions. Six issues seem especially important: 
1. What policies could robustly subordinate the capitalist market economy to democratic constraints in a globalized context? A global superordinate democratic state seems completely out of reach, and in any case, there are no serious models for how this could work. The answer probably involves resolving collective action problems among states more than simply increasing the capacity of individual states to control their own economies. But, when many of the critical states involved are not themselves democratic, and when even the democratic states operate in a political environment of large inequalities of power, it is not at all obvious that in practice successful solutions to coordination problems among states will have a democratic character. And if the solution to coordination problems is fundamentally undemocratic, then it is not at all clear that such solutions would open more space for social progress.

2. What politically achievable mechanisms would generate meaningful global redistribution, especially in the face of global environmental injustice? Stark differences in international living standards are the legacy of uneven economic development. The global economic system does an extremely poor job of protecting poorer countries from the actions of affluent countries (in the area of financial policies, trade restrictions, or global investment and tax regimes), depriving them of much needed resources and imposing huge costs in the form of capital volatility and climate change. As the Maastricht principles make clear, the promise of rich countries to provide 0.7 percent of GDP as aid to developing countries -met by only a handful of states - is inadequate to address these historical and structural inequalities. ${ }^{27}$ All of the proposals outlined above are framed on the national level, and would do little to reduce international

\footnotetext{
${ }^{27}$ Maastricht Principles on Extraterritorial Obligations of States in the Area of Economic, Social and Cultural Rights, available at

https://www.ilsa.org/jessup/jessup17/Batch\%202/Maastricht\%20Principles\%20on\%20Extraterritorial\%200bligation s\%20of\%20States\%20in\%20the\%20Area\%20of\%20Economic,\%20Social\%20and\%20Cultural\%20Rights.pdf
} 
inequalities. At best, they might provide a model for more egalitarian and sustainable economic development.

3. Other legacy effects include inequalities based on ethnicity, race, gender and other dimensions of social identity that would affect the functioning of any alternative economic system. These include major differences in the distribution of financial and human capital—both wealth and education. Some of the identity-based collective conflict we observe in the world is undoubtedly a displacement of underlying economic grievances, and if those grievances were resolved then many distributional conflicts would diminish (Stewart 2008). But some forms of identity-based collective conflict do not simply reflect underlying economic interests and what it would take to fully resolve these identity-based collective conflicts would mean further ethnic, racial and gender transformations.

4. How should family and community life be integrated into the larger economic system in ways that promote real gender equality and human flourishing? Greater provision of public goods, including a basic minimum income and good quality, publicly provided care centers, would improve the position of unpaid caregivers. Policies such as paid paternity leave from work—in "use it or lose it" form—could encourage more participation by fathers. Cultural renegotiation of care responsibilities could challenge constrictive definitions of both femininity and masculinity.

5. How can we improve, and perhaps modify the relationship between material and subjective well-being? Whatever the limits of a happiness metric, the relationship between economic living standards and human satisfaction is far more complex than previously realized. The assumption that "more is always better" programmed into global norms has proved both deceptive and dysfunctional. Yet the desire to improve our position relative to others seems 
deeply embedded and difficult to change. Within wealthy countries, "voluntary simplicity" and non-consumerist life-styles are essential for long-term environmental sustainability, but what kinds of achievable policies could robustly move us in this direction? Is it possible to have a stable market economy without consumerism?

6. What practical strategies can help forge the collective agents necessary for sustainable social progress? The persistence, and sometimes intensification, of identity-based cleavages, especially as these intersect and interact with complex forms of class divisions, makes it very difficult to assemble social forces capable of sustained collective action. This is an urgent problem, not simply because future social progress depends on collective action, but because in the twenty-first century we face a real prospect of catastrophic social regress. In an earlier era, it was thought that the trajectory of social change was producing ever-more homogeneous material conditions of life for the vast majority of people, and thus the task of creating collective actors for struggle would become easier over time. Instead, this task has become more difficult. However insightful are the discussions of intersectionality and heterogeneity of multiple forms of oppression, they do not provide clear answers to the vexing problem of how to overcome these divisions in a robust way. It is easy enough to proclaim the need for a democratic egalitarian coalition for collective action among people with cross-cutting, intersectional identities; it is quite another thing to figure out how to do so.

These are difficult questions. Some of them may, in fact, be unanswerable. Social sciences have proven quite successful in the diagnosis and critique of the world as it is. We know a great deal about the ways in which existing structures and practices generate harms in the world and generate obstacles to social improvement. And we also know a fair amount, with some 
important gaps, about what kinds of changes, if they could be instituted, would make things better. What is much more difficult is understanding how to get from here to there. This is like a doctor that has diagnosed an illness and identified the cure, but cannot get the patient to do what is needed to turn the cure on paper into a cure in reality. Perhaps the patient lacks will power or just doesn't have the material resources needed to follow through with the doctor's recommendations. A critical task for social science in the $21^{\text {st }}$ century is helping to figure out how to actually implement the social, economic and political changes needed for sustainable social progress into the future.

\section{Acknowledgments}

We are grateful to Nick Couldry, Nico Cloete, Ronaldo Munck, and especially Shahrashoub Razavi for detailed engagement with earlier drafts. Leila Gautham provided invaluable assistance with copy editing. 


\section{References}

Acemoglu, Daron and James A. Robinson. 2012. Why Nations Fail. New York: Crown.

Adam, Barbara, and Groves, Chris. 2007. Future Matters. Amsterdam: Brill.

Alesina, Alberto, Reza Baqir, and William Easterly, 1999. "Public Goods and Ethnic Divisions," The Quarterly Journal of Economics (1999) 114 (4): 1243-1284.

Alic, J.A., 2007. Trillions for Military Technology: How the Pentagon Innovates and Why It Costs So Much, New York: Palgrave MacMillan.

Allan, S., Adam, B. and Carter, C., eds. 1999. Environmental Risks and the Media. London: Routledge.

Allen, R., 1992. Waste not, Want not: The Production and Dumping of Toxic Waste, London: Earthscan.

Appadurai, A. 2013. The Future as Cultural Fact: Essays on the Global Condition. London: New York.

Arthur, W. Brian. 2013. “Complexity Economics: A Different Framework for Economic Thought," Santa Fe Institute Working Paper 2013-04-012, available at http://tuvalu.santafe.edu/ wbarthur/Papers/Comp.Econ.SFI.pdf

Atkinson, Anthony B. 2015. Inequality. What Can Be Done? Cambridge, Mass.: Harvard University Press.

Axelrod, Robert. 1997. The Complexity of Cooperation: Agent-Based Models of Competition and Collaboration. Princeton, NY: Princeton University Press.

Bargawi, Hannah, Giovanni Cozzi, and Susan Himmelweit, eds. 2017. Economics and Austerity in Europe: Gendered Impacts and Sustainable Alternatives. New York: Routledge. 
Barro, Robert. 1994. "Democracy: A Recipe for Growth?" The Wall Street Journal, December 1. Beddington, J., 2009. Food, Energy, Water and the Climate: A Perfect Storm of Global Events?, London.

Beeson, M., 2010. “The Coming of Environmental Authoritarianism.” Environmental Politics, 19(2), pp.276-294.

Bengtson, Vern L. and Petrice S. Oyama. 2007. Intergenerational Solidarity: Strengthening Economic and Social Ties. New York: Department of Economic and Social Affairs Division for Social Policy and Development, United Nations. http://www.un.org/esa/socdev/unyin/documents/egm_unhq_oct07_bengtson.pdf

Bhambra, Gurminder K., and Boaventura de Sousa Santos (eds.) 2016. "Global Futures and Epistemologies of the South: New Challenges for Sociology," special issue Sociology, 51(1).

Bloom, A. and W. Breines ed. 2003. Takin' it to the Streets": A Sixties Reader. Oxford: Oxford University Press.

Brady, David, and Hang Young Lee. 2014. “The Rise and Fall of Government Spending in Affluent Democracies, 1971-2008,” Journal of European Social Policy 24:1, 56-79.

Broers, A., 2005. The Triumph of Technology, Cambridge: Cambridge Univ. Press.

Burda, Michael, Daniel S. Hamermesh, and Philippe Weil. 2013. “Total Work and Gender: Facts and Possible Explanations," Journal of Population Economics 26:239-261.

Burke, L., K. Reytar, M. Spalding and A. Perry. 2011. Reefs at Risk Revisited. Washington DC: World Resources Institute.

Carroll, W.K. 2010. The Making of a Transnational Capitalist Class: Corporate Power in the 21st Century. London: Zed. 
Castree, N. and B. Braun, eds. 2001. Social Nature: Theory, Practice and Politics. Oxford: Blackwell.

Charles, Maria, and David B. Grusky. 2004. Occupational Ghettos: The Worldwide Segregation of Women and Men. Stanford, CA: Stanford University Press.

Chesbrough, H., 2003. “The Governance and Performance of Xerox 's Technology Spin-off Companies," Research Policy 32, pp.403-421.

Chou, C. and Shy, O., 2013. "The Crowding-Out Effects of Long Duration of Patents," The RAND Journal of Economics 24(2), pp.304-312.

Christophers, B., 2009. Envisioning Media Power: On Capital and Geographies of Television, Lanham: Lexington Books.

Chua, Amy. 2004. Worlds on Fire. How Exporting Free Market Democracy Breeds Ethnic Hatred and Global Instability. New York: Anchor.

Collingridge, D., 1983. "Hedging and Flexing: Two Ways of Choosing under Ignorance." Technology Forecasting and Social Change, 23, pp.161-172.

Connell, Raewyn. 2014. "Margin Becoming Centre: For a World-Centred Rethinking of Masculinities. NORMA: International Journal for Masculinity Studies, 9(4), 217-231.

Connell, Raewyn, Fran Collyer, João Maia, and Robert Morrell. 2017. “Toward a Global Sociology of Knowledge: Post-colonial Realities and Intellectual Practices," International Sociology, 32(1): 21-37.

Cowen, Tyler. 2013. Average is Over: Powering America Beyond the Age of the Great Stagnation. New York: Dutton.

CPRE, 2013. Going, Going, Gone? England's Disappearing Landscapes, London. 
Cranor, C.F., 2011. Legally Poisoned: How the Law Puts Us at Riskfrom Toxicants, Cambridge MA: Harvard University Press.

Crenshaw, Kimberlé. 1989. "Demarginalizing the Intersection of Race and Sex: A Black Feminist Critique of Antidiscrimination Doctrine, Feminist Theory and Antiracist Politics," University of Chicago Legal Forum, 1(8): 139-167,

Curran, J., 2002. Media and Power, London: Routledge.

Dator, J.A., Sweeney, J.A. and Yee, A.M., 2015. Mutative Media: Communication Technologies and Power Relations in the Past, Present, and Futures, Berlin: Springer.

Davala, Sarath, Renana Jhabvala, Guy Standing, and Soumya Kapoor Mehta. 2015. Basic Income: A Transformative Policy for India. London: Bloomsbury.

Dewey, J. (1935). “The Future of Liberalism.” The Journal of Philosophy, 32(9), 225-230.

Doherty, B. and Geus, M. De eds., 1996. Democracy and Green Political Thought: Sustainability, Rights and Citizenship, London: Routledge.

Donaldson, Mike and Scott Poynting. 2006. Ruling Class Men: Money, Sex, Power. Bern: Peter Lang.

Dosi, G. and Nelson, R.R., 1994. "An Introduction to Evolutionary Theories in Economics.” Journal of Evolutionary Economics, 4, pp.153-172.

Duggan, Lisa. 2003. The Twilight of Equality? Neoliberalism, Cultural Politics, and the Attack on Democracy. Boston: Beacon.

Eastin, Joshua, and Aseem Prakash. 2013. "Economic Development and Gender Equality: Is There a Gender Kuznets Curve?" World Politics 65(1), 156-86.

Edwards, D. and Cromwell, D., 2006. Guardians of Power: The Myth of the Liberal Media, London: Pluto Press. 
Elborgh-Woytek, Monique Newiak, Kalpana Kochbar, Stefania Fabrizio, Phillipe Wingender. 2013. Women, Work, and the Economy; Macroeconomic Gains from Gender Equity. No 13/10, IMF Staff Discussion Notes from International Monetary Fund No. 13/10, available at http://econpapers.repec.org/paper/imfimfsdn/13_2f10.htm, accessed May 24, 2017.

Elias, N. 1996. Du Temps, traduit de l'allemand par Michèle Hulin. Paris: Fayard.

Eurobarometer, 2005. Population Innovation Readiness, Brussels.

Fagerberg, J., 2003. "Schumpeter and the Revival of Evolutionary Economics: An Appraisal of the Literature." Journal of Evolutionary Economics, 13(2), pp.125-159.

FAIC, 2012. The Fukushima Nuclear Accident Independent Investigation Commission, Tokyo.

FAO \& WWC, 2015. Towards a Water and Food Secure Future: Critical Perspectives for Policy-makers, Rome.

Felt, U. et al., 2008. Taking European Knowledge Society Seriously: Report of the Expert Group on Science and Governance to the Science, Economy and Society Directorate, Directorate-General for Research, European Commission U. Felt \& B. Wynne, eds., Brussels: European Commission.

Felt, U. et al., 2013. Science in Society: Caring for Our Futures in Turbulent Times, Strasbourg: European Science Foundation.

Ferreras, Isabelle. 2017. Firms as Political Entities. Saving Democracy through Economic Bicameralism. New York: Cambridge University Press

Fiske, Susan. 2012. Envy Up, Scorn Down: How Status Divides Us. New York: Russell Sage Foundation. 
Folbre, Nancy. 2008. Valuing Children: Rethinking the Economics of the Family. Cambridge, MA: Harvard University Press.

Folbre, Nancy. 2013. "The Rise and Decline of Patriarchal Capitalism," in Robert Pollin and Jeannette Wicks-Lim, editors, Capitalism on Trial: Explorations in the Tradition of Thomas E. Weisskopf. Cheltenham, UK: Edward Elgar.

Folbre, Nancy. 2016. "Just Deserts? Earnings Inequality and Bargaining Power in the U.S. Economy.” Washington Center for Equitable Growth Working Paper, available at http://equitablegrowth.org/working-papers/earnings-inequality-and-bargaining-power/, accessed December 13, 2016.

Frank, Andre Gunder. 1967. Capitalism and Underdevelopment in Latin America. New York: Monthly Review Press. .

Freire, P., 2001. Pedagogy of Freedom: Ethics, Democracy and Civic Courage, Lanham MA: Rowman \& Littlefield Publishers.

Gastil, John, and Erik Olin Wright. Forthcoming. Legislature by Lot. London: Verso.

Gee, D. et al. eds., 2013. Late Lessons from Early Warnings: Science, Precaution, Innovation, Copenhagen: European Environment Agency.

Geels, F.W., 2006. “The Hygienic Transition from Cesspools to Sewer Systems (1840-1930): The Dynamics of Regime Rransformation.” Research Policy, 35(7), pp.1069-1082.

Gibson-Graham, J.K. 1996. The End of Capitalism (as We Knew it). Ann Arbor: University of Michigan Press.

Gloor, P.A., 2006. Swarm Creativity: Competitive Advantage Through Collaborative Innovation Networks, Oxford: Oxford University Press. 
Goldman, M. and Schurman, R.A., 2000. "Closing the "Great Divide": New Social Theory on Society and Nature.” Annual Review of Sociology, 26, pp.563-584.

Graham, Mark, Hale, S. A., and Stephens, M. (2011) Geographies of the World's Knowledge. London, Convoco! Edition. Available at https://www.oii.ox.ac.uk/archive/downloads/publications/convoco_geographies_en.pdf

Grieder, William. 1997. One World Ready or Not. New York: Simon and Schuster.

Grossman, E. 2006. High Tech Trash: Digital Devices, Hidden Toxics, and Human Health, Washington: Island Press.

Grove, R.H. 1995. Green Imperialism: Colonial Expansion, Tropical Island Edens and the Origins of Environmentalism, Cambridge: Cambridge Univ. Press.

Hajer, M. et al. 2015. "Beyond Cockpit-ism: Four Insights to Enhance the Transformative Potential of the Sustainable Development Goals.” Sustainability, (February), pp.16511660.

Hamilton, C., Bonneuil, C. and Gemenne, F. eds. 2015. The Anthropocene and the Global Environmental Crisis: Rethinking Modernity in a New Epoch, London: Routledge.

Hansmann, Henry. 2000. The Ownership of Enterprise. Harvard University Press, 2000.

Harremoës, P. et al. ed. 2002. The Precautionary Principle in the Twentieth Century: Late Lessons from Early Warnings. Earthscan Publications.

Hearn, Jeff and Liisa Husu. 2016. “Gender Equality.” In Nancy Naples et al. (eds.) The Wiley Blackwell Encyclopedia of Gender and Sexuality Studies. Oxford: Wiley-Blackwell. Hearn, Jeff. 1999. “Ageism, Violence and Abuse: Theoretical and Practical Perspectives on the Links between Child Abuse and Elder Abuse," 81-96 in The Violence Against Children 
Study Group Children, Child Abuse and Child Protection: Placing Children Centrally. London: John Wiley.

Hearn, Jeff. 2015. Men of the World: Genders, Globalizations, Transnational Times. London: Sage.

Hess, D.J., 2016. Undone Science: Social Movements, Mobilized Publics, and Industrial Transitions, Cambridge MA: MIT Press.

Hess, S. and Kalb, M. eds. 2003. The Media and the War on Terrorism, Washington DC: Brookings Institution.

Hickman, L. 2010. "James Lovelock: Humans are too Stupid to Prevent Climate Change." Guardian, (29 March), pp.2-5.

Hilgartner, S. 2009. "Intellectual Property and the Politics of Emerging Technology: Inventors, Citizens, and Powers to Shape the Future. Chicago-Kent Law Review, 81(1), pp.197-224. Hills, John. 2014. Good Times, Bad Times: The Welfare Myth of Them and Us. Bristol, UK: Policy Press.

Holter, Øystein Gullvåg. 2014. “'What's In It for Men?’ Old Question, New Data,” Men and Masculinities 17(5): 515-548.

Hountondji, Paulin J. 1997. "Introduction: Recentring Africa.” In Paulin J. Hountondji (ed.), Endogenous Knowledge: Research Trails (pp. 1-39). Dakar: CODESRIA.

Huesemann, M.H., 2003. "The Limits of Technological Solutions to Sustainable Development." Clean Technology and Environment Policy, 5, pp.21-34.

IAASTD. 2009. Agriculture at a Crossroads: International Assessment of Agricultural Knowledge Science and Technology for Development (IAASTD), Washington: Island Press. 
IPCC. 2015. Climate Change 2014 - Synthesis Report, Geneva: IPCC.

Itzigsohn, José and Julián Rebón. 2016.The Recuperation of Enterprises: Defending Workers’ Lifeworld, Creating New Tools of Contention," Latin American Research Review, 50 (4), $178-196$.

Joergensen, U. and Karnoe, P. 1991. "The Danish Wind Turbine Story - Technical Solutions to Political Visions?” In A. Rip, J, Mise. And J. Schot (eds), Managing Technology in Society: The Approach of Constructive Technology Assessment. London: Pinter Publishers, p. 57-82.

Jonas, O.B., 2013. Pandemic Risk, Washington.

Kalleberg, Arne. 2011. Good Jobs, Bad Jobs: The Rise of Polarized and Precarious Employment Systems in the United States, 1970s to 2000s. New York: Russell Sage Foundation. Kaplinsky, R. 2000. “Globalisation and Unequalisation: What Can Be Learned from Value Chain Analysis?” Journal of Development Studies, 37(2), pp.117-146.

Kennedy, J., Eberhart, R.C. and Shi, Y. 2001. Swarm Intelligence, San Francisco: Morgan Kaufman.

Koselleck, R. (2004). Futures Past: On the Semantics of Historical Time. Columbia University Press.

Le, E., 2010. Editorials and the Power of the Media, Amsterdam: John Benjamins Publishing. Leach, M., Scoones, I. and Stirling, A. 2010. Dynamic Sustainabilities: Technology, Environment, Social Justice, London: Routledge.

Lin, Ken-Hou and Donald Tomaskovic-Devey. 2013. "Financialization and U.S. Income Inequality, 1970-2008," American Journal of Sociology 118(5), 1284-1329. 
Lindert, Peter H. 2004. Growing Public, Volumes I and II. New York: Cambridge University Press.

Luhmann, N. 1995. Social Systems. Stanford University Press.

Mankiw, N. Gregory. 2013. "Defending the One Percent," Journal of Economic Perspectives $27: 3$, p. 29 .

Marshall, T. H. (1950). Citizenship and Social Class, and Other Essays. Cambridge: Cambridge University Press.

Mbembe, Achille. 2001. On the Postcolony. Berkeley, CA: University of California Press.

MEA, 2008. Ecosystems and Human Well-Being - Volume 3: Policy Responses, New York: Island Press.

Meadows, D.H., Randers, J. and Meadows, D.L., 2005. The Limits to Growth: The 30-year Update, London: Earthscan.

Mies, Maria. 1999. Patriarchy and Accumulation on a World Scale: Women in the International Division of Labour. London: Zed.

Milanovic, Branko. 2012. The Haves and the Have-Nots. New York: Basic Books.

Mills, Charles W. 1999. The Racial Contract. Ithaca, NY: Cornell University Press.

Morel, Nathalie, Bruno Palier, and Joakim Palme, eds. 2012. Towards a Social Investment Welfare State? Ideas, Policies and Challenges. Chicago: Policy Press.

Muñoz-Erickson, T.A. and Cutts, B.B. 2016. "Structural Dimensions of Knowledge-Action Networks for Sustainability." Current Opinion in Environmental Sustainability, 18, pp.56-64.

Murray, Charles. 2006. In Our Hands: A Plan to Replace the Welfare State. Washington, DC: AEI Press. 
Neil, F. and McAdam, D. 2010. "Toward a General Theory of Strategic Action Fields." Sociological Theory.

Neill, J., 2016. Tackling Drug-resistant Infections Globally: Final Report and Recommendations the Review on Antimicrobial Resistance, London.

Nelson, R.R. and Winter, S.G., 1977. "In Search of a Useful Theory of Innovation.” Research Policy, 6, pp.36-76.

Neumayer, E. 2011. Sustainability and Inequality in Human Development. United Nations Development Programme, Human Development Reports, Research Paper 2011/04.

Norgaard, R.B. 1994. Development Betrayed: The End of Progress and a Coevolutionary Revisioning of the Future, London: Routledge.

OECD, 2010. The OECD Innovation Strategy: Getting a Head Start on Tomorrow - Executive Summary, Paris.

OECD, 2012. Environmental Outlook to 2050, Paris, France.

OECD, 2013. Main Science and Technology Indicators: Volume 2013/1,

Oleksy, Elzbieta, Jeff Hearn, and Dorota Golanska. eds. 2011._The Limits of Gendered Citizenship: Contexts and Contradictions. New York: Routledge.

Ophuls, W., 1997. Requiem for Modern Politics The Tragedy of the Enlightenment and the Challenge of the New Millennium, Boulder, Colorado: Westview.

Orenstein, Mitchell. 2008. "Post-Communist Welfare States," Journal of Democracy (October), 80-94.

OTA, 1979. The Effects of Nuclear War, Washington: United States Congress Office of Technology Assessment.

Paxton, Robert O. 2004. The Anatomy of Fascism. New York: Knopf. 
Pease, Bob. 2010. Undoing Privilege: Unearned Advantage in a Divided World. London: Zed.

Pellizzoni, L., 2004. "Responsibility and Environmental Governance.” Environmental Politics, 13(3), pp.541-565.

Perreaul, T., Bridge, G. and McCarthy, J. eds. 2015. The Routledge Handbook of Political Ecology, London: Routledge.

Petmesidou, Maria, and Ana M. Guillén. 2014. "Can the Welfare State as We Know It Survive? A View from the Crisis-Ridden South European Periphery," South European Society and Politics 19 (3), 295-307.

Petras, James. 2012. "The Western Welfare State: Its Rise and Demise and the Soviet Bloc," Global Research Report, available at http://www.globalresearch.ca/the-western-welfarestate-its-rise-and-demise-and-the-soviet-bloc/31753

Phaal, R., Farrukh, C.J.P. and Probert, D.R. 2004. “Technology Roadmapping — A Planning Framework for Evolution and Revolution. Technology Forecasting and Social Change, 71, pp.5-26.

Piketty, Thomas. 2014. Capital in the Twenty-First Century. Cambridge, MA: Harvard University Press.

Pope, Kenneth S. 2015. “Are the American Psychological Association’s Detainee Interrogation Policies Ethical and Effective?” Zeitschrift für Psychologie 219:3, 150-158.

Porte, T.R. la ed. 1991. Social Responses to Large Technical Systems: Control or Anticipation, The Netherlands: Kluwer Academic Publishers

Puar, Jasbir. 2007. Terrorist Assemblages: Homonationalism in Queer Times. Durham, NC: Duke University Press.

Rannis, Peter. 2016. Cooperatives Confront Capitalism. London: Zed Books. 
Rawls, J., 1999. A Theory of Justice, Cambridge MA: Belknap Press.

Rebón, Julian. 2007. La Empresa de la Autonomía. Trabajadores Recuperando la Producción. Buenos Aires: Colectivo Ediciones-Ediciones PICASO.

Redclift, M., 1987. Sustainable Development: Exploring the Contradictions, London: Routledge. Rockström, J. et al. 2009. “A Safe Operating Space for Humanity.” Nature, 461(24 September), pp.472-475.

Roy, Arundhati. 2004. An Ordinary Person's Guide to Empire. Cambridge, MA: South End Press.

Said, Edward. 1978. Orientalism. New York: Pantheon.

Samuelson, Paul. 1957. "Wages and Interest: a Modern Dissection of Marxian Economic Models," American Economic Review 47(6): 884-912

Santos, Boaventura de Sousa. 2014. Epistemologies of the South. Boulder, CO: Paradigm.

Science, G.O. for. 2014a. Annual Report of the Government Chief Scientific Adviser 2014 Innovation: Managing Risk, not Avoiding it - report overview,

Science, G.O. for. 2014b. Innovation: Managing Risk, not Avoiding it - Evidence and Case Studies (Annual Report of the Government Chief Scientific Adviser 2014), London.

Shepherd, J. et al. 2009. Geoengineering the Climate: Science, Governance and Uncertainty, London: The Royal Society.

Singer, P. 2002. Animal Liberation, London: Harper Collins.

Sintomer, Y. 2011. Petite Histoire de L'expérimentation Démocratique: Tirage au Sort et Politique d'Athènes à nos Jours. Paris: La Découverte.

Sklair, Leslie. 2001. The Transnational Capitalist Class. Oxford: Blackwell.

Smith, A. et al. 2016. Grassroots Innovation Movements, London: Routledge Earthscan. 
Spade, Dean. 2011. Normal Life: Administrative Violence, Critical Trans Politics and the Limits of Law. Cambridge, MA: South End.

Spivak, Gayatri Chakravorty. 1987. In Other Worlds: Essays in Cultural Politics. New York: Methuen.

Standing, Guy. 1999. “Global Feminization Through Flexible Labor: A Theme Revisited,” World Development 27(3), 583-602.

Standing, Guy. 2011. The Precariat: The New Dangerous Class. London: Bloomsbury Academic.

Steans, Jill. 2013. Gender and International Relations, 3rd ed. Cambridge: Polity.

Stewart, Frances, ed. 2008. Horizontal Inequalities and Conflict. New York: Palgrave.

Stiglitz, Joseph, Amartya Sen and Jean-Paul Fitoussi. 2009. Report by the Commission on Economic Performance and Social Progress Revisited. OFCE - Center de Recherche en Economie de Sciences Po, available at

Stirling, A. 2008. “Opening Up" and "Closing Down”: Power, Participation, and Pluralism in the Social Appraisal of Technology.” Science, Technology and Human Values, 23(2), pp.262-294.

Stirling, A. 2010. "From Enlightenment to Enablement: Opening up Choices for Innovation.” In A. Lopez-Claros, ed. The Innovation for Development Report. Basingstoke: Palgrave Macmillan, pp. 199-210.

Stirling, A. 2011. "Pluralising Progress: From Integrative Transitions to Transformative Diversity.” Environmental Innovation and Societal Transitions, 1(1), pp.82-88.

Stirling, A. 2012. "Opening Up the Politics of Knowledge and Power in Bioscience.” PLoS Biol, 10(1), p.e1001233. 
Stirling, A. 2014a. “Towards Innovation Democracy: Participation, Responsibility and Precaution in Innovation Governance.” In Annual Report of the Government Chief Scientific Adviser 2014, Innovation: Managing Risk, Not Avoiding It. Evidence and Case Studies, London: Government Office of Science, https://www.gov.uk/government/uploads/system/uploads/attachment_data/file/376505/14. London? UK Government, pp. 49-62,.

Stirling, A. 2014b. "Transforming Power: Social science and the Politics of Energy Choices." Energy Research and Social Science, 1, pp.83-95.

Stirling, A. 2015. "Emancipating Transformations: From Controlling "the Transition" to Culturing Plural Radical Progress.” In I. Scoones, M. Leach, and P. Newell, eds. The Politics of Green Transformations. London, pp. 54-67.

Stirling, A. 2016. “Knowing Doing Governing: Realizing Heterodyne Democracies.” In J.-P. Voß \& R. Freeman, eds. Knowing Governance: The Epistemic Construction of Political Order. Basingstoke: Palgrave Macmillan.

Streeck, Wolfgang. 2016. How Will Capitalism End? New York: Verso.

Scambor, Elli, Katarzyna Wojnicka, Nadja Bergmann, eds. 2013. The Role of Men in Gender Equality: European Strategies and Insights. Luxembourg: European Union.

Sveiby, Karl-Erik, Pernilla Gripenberg and Beata Segercrantz, eds. 2012. Challenging the Innovation Paradigm. New York: Routledge.

Thompson, E.P. 1978. The Poverty of Theory and Other Essays. New York: New York University Press.

Tronto, Joan. 2013. Caring Democracy: Markets, Equality and Justice. New York: NYU Press. 
UN.2015. World Population Prospects: Key Findings and Advance Tables. New York: United Nations.

UNCTAD and CGIAR. 2013. Wake Up Before It Is Too Late: Make Agriculture Truly Sustainable for Food Security in a Changing Climate, Geneva.

UNDESA. 2015. World Urbanization Prospects - the 2014 revision, New York: UNDESA.

UNEP et al. 2014. Assessing Global Land Use: Balancing Consumption with Sustainable Supply, New York: United Nations Environment Programme.

UNRISD (United Nations Research Institute for Social Development). 2010. Combating Poverty and Inequality: Structural Change, Social Policy and Politics. Geneva: UNRISD, available at www.unrisd.org

UNRISD (United Nations Research Institute for Social Development). 2016. Understanding Transformation for Sustainable Development. Geneva: UNRISD, available at www.unrisd.org.

UNSCEAR, 2017. UNSCEAR 2016 Report: Sources, Effects, and Risks of Ionizing Radiation: Report to the General Assembly, New York: United Nations

UNWomen. 2015. The Progress of the World's Women. Transforming Economies, Realizing Rights. Available on line at http://progress.unwomen.org/en/2015/, accessed March 30, 2017.

Van Parijs, Philippe and Yannick Vanderborght. 2017. Basic Income: A Radical Proposal for a Free Society and a Sane Economy (Cambridge: Harvard University Press)

Veld, R.J. ed. 2010. Knowledge Democracy: Consequences for Science, Politics and the Media, Heidelberg: Springer. 
Verloo, Mieke. 2006. "Multiple Inequalities, Intersectionality and the European Union," European Journal of Women's Studies 13(3): 211-228.

WEF, Waughray, D. and Workman, J.G. 2014. "Water Security: The Water-Food-EnergyClimate Nexus," Igarss 2014, (1), pp.1-5.

Weil, David N. 2015. "Capital and Wealth in the Twenty-First Century," American Economic Review 105(5): 34-37.

Weiser, Wendy, "Voter Suppression: How Bad? (Pretty Bad)," The American Prospect, Oct. 1, 2014, available at http://prospect.org/article/22-states-wave-new-voting-restrictionsthreatens-shift-outcomes-tight-races, accessed December 11, 2016.

WHO, 2015. WHO Estimates of the Global Burden of Foodborne Diseases, Rome: World Health Organisation.

Wilkinson, Richard G., and Pickett, Kate. 2009. The Spirit Level: Why Greater Equality Makes Societies Stronger. London: Allen Lane.

Williams, R. and Edge, D. 1996. "The Social Shaping of Technology,” Research Policy, 25(6), pp.865-899.

Wilson, William J. 2012. The Declining Significance of Race: Blacks and Changing American Institutions, Third Edition. Chicago: University of Chicago Press, 2012.

World Bank, 2007. World Development Indicators. http://data.worldbank.org/products/databooks/WDI-2007

World Resources Institute (World Resources Institute, Carbon Analysis Indicators Tool, http://cait.wri.org/

Wright, Erik Olin. 1998. Classes. New York: Verso.

Wright, Erik Olin. 2010. Envisioning Real Utopias. New York: Verso. 
Wright, Erik Olin. 2011. “Real Utopias,” Contexts, Spring 2011, pp. 37-42.

Wright, Erik Olin. 2015, "How to be an Anticapitalist Today," Jacobin (on line), 12.2.15. https://www.jacobinmag.com/2015/12/erik-olin-wright-real-utopias-anticapitalismdemocracy/

Young, Brigitte, Isabel Bakker and Diane Elson, eds. 2011. Questioning Financial Governance from a Feminist Perspective. London: Routledge.

Zuboff, Shoshana. 2015. "Big Other: Surveillance Capitalism and the Prospects of an Information Civilization,” Journal of Information Technology 30, 75-89.

Zucman, Gabriel. 2014. “Taxing Across Borders: Tracking Personal Wealth and Corporate Profits," Journal of Economic Perspectives 28 (4): 121-48. 